Portland State University

PDXScholar

7-11-1995

Renal Responses to Differential Rates of Blood Volume Expansion in the Toad, Bufo marinus

Mark Edward Bolke

Portland State University

Follow this and additional works at: https://pdxscholar.library.pdx.edu/open_access_etds

Part of the Biology Commons

Let us know how access to this document benefits you.

Recommended Citation

Bolke, Mark Edward, "Renal Responses to Differential Rates of Blood Volume Expansion in the Toad, Bufo marinus" (1995). Dissertations and Theses. Paper 4973.

https://doi.org/10.15760/etd.6849

This Thesis is brought to you for free and open access. It has been accepted for inclusion in Dissertations and Theses by an authorized administrator of PDXScholar. Please contact us if we can make this document more accessible: pdxscholar@pdx.edu. 


\section{THESIS APPROVAL}

The abstract and thesis of Mark Edward Bolke for the Master of Science in Biology were presented on July 11, 1995, and accepted by the thesis committee and the department.

COMMITTEE APPROVALS:

Stanley 8. Hillyan, Chair

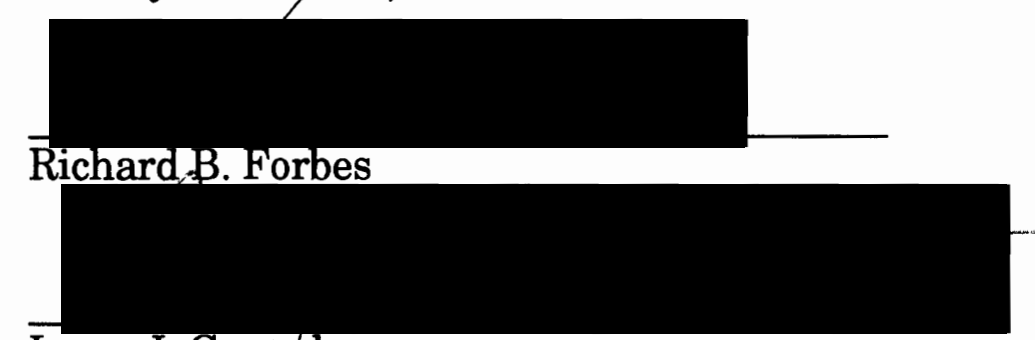

Larry 1. Crawshaw

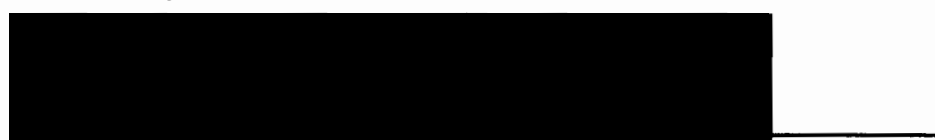

Gary R. Brodowicz

Representative of the Office of Graduate Studies

DEPARTMENT APPROVAL:

Leonard Simpson, Chair

Department of Biology

ACCEPTED FOR PORTLAND STATE UNIVERSITY BY THE LIBRARY by on 13 teptemen 1995 


\begin{abstract}
An abstract of the thesis of Mark Edward Bolke for the Master of Science in Biology presented July 11, 1995.
\end{abstract}

Title: Renal Responses to Differential Rates of Blood Volume Expansion in the Toad, Bufo marinus

Three aspects of renal function were measured in the toad, Bufo marinus ( $\mathrm{N}=10)$ : (1) effect of rate of blood volume expansion on renal functions (UFR; GFR; urine and plasma ion concentrations; and ion excretion rates), (2) effect of hypo- and hyperosmotic blood volume expansions on renal functions, and (3) role of GFR and tubular processes in the differential response of UFR under different osmotic expansion stresses. Renal responses to differential rates of blood volume expansion have not been investigated in amphibians. Rate responses will be analyzed considering effects: (1) during infusion (neural, or, short term regulation of extracellular fluid volume) and (2) post infusion (hormonal, or, long term regulation of extracellular fluid volume).

Volume expansions were administered with hypoosmotic $(0.4 \%)$ saline and hyperosmotic (1.4\%) saline, and ranged in rate from 4.0 to 20.6 $\mathrm{ml} / \mathrm{kg} / \mathrm{min}$. This protocol is designed to present volume regulatory mechanisms with increased volume stimuli and different osmotic stimuli.

Overall, infusion rate had no significant effects on renal responses measured: urine flow rate (UFR); glomerular filtration rate (GFR); urine and plasma ion concentrations; natriuresis; or kaliuresis. This was true for the 
infusion period and for the observed post infusion period (90 min). Rate was correlated with GFR in the hypoosmotic group $(r=0.30, p=0.04)$ and natriuresis in the hyperosmotic group $(r=0.34, p=0.03)$.

A significant positive correlation was observed between UFR and GFR. Relative to treatment, UFR differed significantly; GFR response was inherently similar despite differences at individual intervals, indicating UFR differences between the treatments is due to tubular processes.

Responses to hypoosmotic infusion included a significant diuresis, natriuresis, and a decreased urine sodium concentration, relative to hyperosmotic infusion. At low UFRs the hyperosmotic group produced urine relatively concentrated in sodium.

Urine sodium concentration and UFR were positively correlated in the hypoosmotic infusion group -- at high UFRs, kidneys were unable to produce a dilute urine. 


\title{
RENAL RESPONSES TO DIFFERENTIAL RATES OF BLOOD VOLUME EXPANSION \\ IN THE TOAD, Bufo marinus
}

\author{
by \\ MARK EDWARD BOLKE
}

A thesis submitted in partial fulfillment of the requirements for the degree of

\author{
MASTER OF SCIENCE \\ in \\ BIOLOGY
}

Portland State University

1995 


\section{ACKNOWLEDGEMENTS}

I would like to acknowledge the following people for their support and inspiration. In one way or another, they are all a part of this thesis.

Dr. Stan Hillman, for his guidance, confidence, wisdom, "know-how", and Hillman logic.

The committee members, Dr. Larry Crawshaw, Dr. Gary Brodowicz, and Dr. Richard Forbes for their time and review of the draft. Special thanks to Dr. Forbes for invaluable and immeasurable input and also for being one of the finest people I've ever known.

The boys in the swamp, Ed, Dane, Jonn, and Brian whose antics and intellectual discussions yielded laughter and enlightenment.

Leslee Parr for inspiring me with her tenacious pursuit of life and science, also for her friendship and encouragement.

Jim Campbell for inspiration and confidence.

Michelle, my wife, for endless support, encouragement, and love.

Little Conor, my newly arrived son, who has taught me the importance of the little things and the need to finish the big things. 
TABLE OF CONTENTS

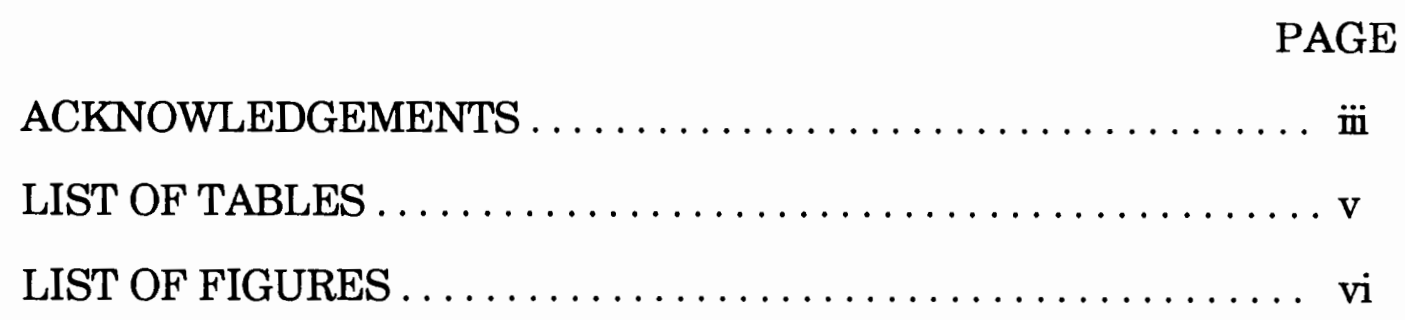

INTRODUCTION ........................... 1

REVIEW OF THE LITERATURE. . . . . . . . . . . . . . 3

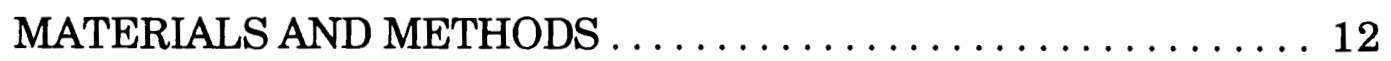

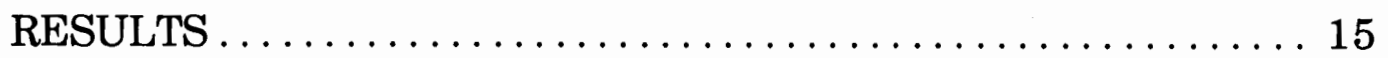

Pre-infusion Comparisons . . . . . . . . . . . . 15

Hematocrit ........................ 16

Infusion Rate . . . . . . . . . . . . . . . . 17

Electrolytes ....................... 18

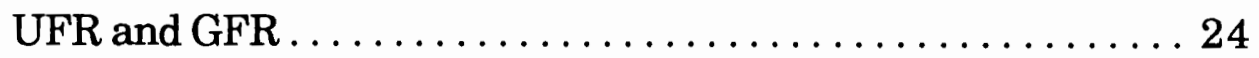

Ion Excretion $\ldots \ldots \ldots \ldots \ldots \ldots \ldots \ldots \ldots \ldots \ldots \ldots \ldots \ldots$

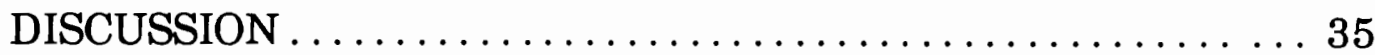

Hematocrit ......................... 35

Infusion Rate . . . . . . . . . . . . . . . . . . . 35

UFR and GFR $\ldots \ldots \ldots \ldots \ldots \ldots \ldots \ldots \ldots \ldots \ldots \ldots \ldots \ldots \ldots$

Electrolytes .......................... 39

SUMMARY ............................. 44

REFERENCES CITED . . . . . . . . . . . . . . . . 46 
LIST OF TABLES

TABLE

PAGE

I Comparison of pre-infusion for renal functions . . . . . . 15

II Correlation coefficients for infusion rate and renal responses during the infusion period $\ldots \ldots \ldots \ldots 17$

III Correlation coefficients for infusion rate and renal responses post infusion period $\ldots \ldots \ldots \ldots \ldots$

IV Tukey test results of urine sodium concentration response relative to pre-infusion values of urine sodium concentration . . . . . . . . . 21

V Standardized $(\beta)$ regression weights of independent variables on urine sodium concentration and corresponding multiple correlation coefficients . . . . 22

VI Correlation coefficients of UFR and GFR .......... 28

VII Standardized ( $\beta$ ) regression weights of independent variables on UFR and corresponding multiple correlation coefficients . . . . . . . . . . . . 28

VIII Standardized $(\beta)$ regression weights of independent variables on urine potassium concentration and corresponding multiple correlation coefficients . . . 30

IX Standardized ( $\beta$ ) regression weights of independent variables on natriuresis and corresponding multiple correlation coefficients

X Standardized ( $\beta$ ) regression weights of independent variables on kaliuresis and corresponding multiple correlation coefficients. . . . . . . . . . . . . 34 


\section{LIST OF FIGURES}

1. Experimental model

2. Effect of treatment on hematocrit ............. 16

3. Effect of treatment on plasma sodium concentration .... 19

4. Effect of treatment on urine sodium concentration ..... 20

5. Effect of treatment on plasma potassium concentration . . 23

6. Effect of treatment on urine potassium concentration ... 24

7. Effect of treatment on urine flow rate (UFR) . . . . . . 25

8. Effect of treatment on glomerular filtration rate (GFR) . 26

9. Correlation of UFR and GFR. .............. 27

10. Correlation of UFR and urine sodium concentration. . . . . 29

11. Correlation of UFR and urine potassium concentration ... 30

12. Effect of treatment on natriuresis . . . . . . . . . 31

13. Effect of treatment on kaliuresis ............... 33 


\section{INTRODUCTION}

At the physiological interface of aquatic life and terrestrial life, amphibians make good models for water balance studies. Kidneys, lymph hearts, nephrostomes, and the urinary bladder all function as regulatory organs of blood volume and composition in amphibians. Investigation of renal response to blood volume and changes in osmotic pressure sheds light on processes involved and the mechanisms behind these processes. Volume expansion protocols have been used for decades (Adolph 1927) to apply various stresses to volume regulatory systems.

Hyperosmotic volume expansion presents two separate signals to the animal; 1) a volume stimulus that under normal circumstances would elicit a diuresis (Adolph 1927), and 2) an osmotic stimulus that alone would elicit an antidiuresis (Schmidt-Nielsen and Forster 1954). Hyperosmotic volume expansion allows these stimuli to be administered simultaneously. The renal responses to hyperosmotic expansion are similar to those observed during dehydration--reduced urine flow rate (UFR) and glomerular filtration rate (GFR), and increased tubular reabsorption (Eliassen and Jørgensen 1951; Schmidt-Nielsen and Forster 1954; Sawyer 1957).

Hypoosmotic expansions present dual signals of excess volume and diluted concentrations of electrolytes, which both elicit diuresis (Adolph 1927; Sawyer 1951). Increased GFR and decreased tubular reabsorption are correlated with hypoosmotic expansion-induced diuresis (SchmidtNielsen and Forster 1954; Sawyer 1957). Blood volume expansion experiments are excellent models for studies of renal function because of the kidney's inherent role in blood volume regulation. 
There are no data for the renal responses to differential blood volume expansion rates in amphibians. Hillman and Schimpf (1994) volume expanded $B$. marinus at a constant infusion rate without accounting for the mass of individual toads. While this protocol results in different infusion rates for each animal due to variation of body mass, this was not one of their variables. By varying the expansion rate one can determine if this factor elicits rate-dependent renal responses. Hillman and Schimpf (1994) observed dramatic differences between treatments in UFRs (hypo- and isosmotic expansions resulted in diuresis while hyperosmotic expansion resulted in diuresis). This variation in UFR may be a result of differences in either GFR or tubular reabsorption. Inclusion of GFR measurements would answer this question of UFR variability. This thesis examines (1) the role of rate of blood volume expansion on amphibian renal functions (UFR; GFR; urine and plasma sodium and potassium concentrations; and ion excretion rates), (2) the influence of hypo- and hyperosmotic blood volume expansions on renal functions, and (3) the role of GFR and tubular processes in the differential response of UFR under different osmotic expansion stresses in the toad, Bufo marinus. Observations of the rate responses will be twofold: consideration of effects (1) during the infusion (neural, or, short term regulation of extracellular fluid volume) and (2) post infusion (hormonal, or, long term regulation of extracellular fluid volume). 


\section{REVIEW OF THE LITERATURE}

A necessary and vital condition of life is the maintenance of homeostasis. An important aspect of homeostasis is the constancy of the internal environment, which is consists of the extracellular fluid, composed of blood plasma, lymph, and interstitial fluid. Cells of multicellular organisms are continually bathed in extracellular fluid. Their normal physiologic function and, thus, that of the organism is dependent on the homeostasis of the fluid.

Vertebrate kidneys are major effector organs in the regulation of homeostasis of the body fluids. Kidneys participate in regulating the volume and composition of blood plasma, and thus determine concentrations of interstitial fluid. Homeostasis of extracellular fluid concentration and volume is a result of the kidney processes of filtration, reabsorption, and secretion. Fluid volume is a direct result of sodium concentration in extracellular fluid (Guyton 1991). Sodium, as the prevalent ion in extracellular fluid, provides the majority of the osmotic pressure of the extracellular fluid. Therefore, sodium concentration indirectly determines the volume of the extracellular fluid. Hemodynamics (Guyton 1991), concentrations of electrolytes other than sodium (Persson and Persson 1981), hormones ( Sawyer 1951, 1957; Pang et al. 1980; Lang et al. 1987), and the nervous system (Morris and Gibbins 1983) also influence renal function.

Amphibians occupy a key position in vertebrate phylogeny. Ancestral amphibians made the transition from an aquatic to a terrestrial environment. Living amphibians may be characterized as aquatic species, 
which spend their lives in water, and terrestrial species, some of which return to water only for reproduction purposes.

The terrestrial invasion carried with it a host of physiological challenges to osmoregulation. Water balance had to be maintained in the terrestrial mode of life despite the relative scarcity of water and increased driving force for evaporative and convective water losses.

Water balance for terrestrial amphibians is the sum of input and output. Input is comprised of cutaneous uptake, preformed water from food, and metabolic water. Output is comprised of cutaneous and respiratory evaporation, and urinary and fecal losses. Evaporative water loss for most amphibian species approaches that of a free surface of water due to their highly permeable skin (Spotila and Berman 1976). Dehydration is much more of a challenge in terrestrial life as opposed to that of an aquatic life, where cutaneous osmotic influx is continuous. Terrestrial species are able to withstand remarkable dehydration. Hillman (1980) showed that some bufonids tolerated dehydration to greater than $40 \%$ of body mass.

Dehydration presents amphibians with the cardiovascular stresses of hypovolemia, hyperosmolality, and hyperviscosity (Hillman 1978a; Hillman 1978b; Hillman et al. 1985). Management of these stresses is crucial for survival.

Increases in blood volume are generally hypoosmotic; i.e., anurans experience cutaneous influx of water which increases plasma volume while decreasing plasma osmotic concentration. Experimental hyperosmotic expansion is not natural for these animals, but it allows study of effects of volume expansion coupled with an increase in osmotic pressure. In contrast to that of mammals, urine formed by the amphibian kidney is subject to 
modification in the bladder, where solutes and water may be reabsorbed to meet osmoregulatory needs (Middler et al. 1968; Bentley 1973). Therefore, to evaluate kidney function urine must be collected by ureteral catheterization.

Amphibians differ from other vertebrates as osmoregulation is accomplished by the skin and bladder as well as the kidneys. The skin and bladder may have profound impacts on body fluid composition depending on hydrational state and presence of circulating hormones which influence bladder and cutaneous transport processes (Bentley 1966; 1976).

The functional unit of the vertebrate kidney is the nephron. The nephron consists of the glomerulus, Bowman's capsule, and a tubule which is functionally and histologically separated into proximal, intermediate, and distal portions. Functionally, the glomerulus is a leaky capillary bed. Blood is delivered to glomeruli via afferent arterioles and exits via efferent arterioles. Blood delivered to the glomerulus is under relatively high pressure because of the relatively short renal arteries and their proximity to the ventricle. Plasma is filtered across the membranes of the glomerulus and Bowman's capsule into the lumen of Bowman's capsule, driven by hydrostatic pressure. The filtration is non-specific, passing all plasma constituents except large plasma proteins, so the filtrate is nearly identical to blood plasma. Nutrients and ions are reabsorbed by active transport processes in the proximal tubule, thus avoiding depletion. Plasma proteins (albumins) are too large to pass; they partially affect hydrostatic filtration via the exertion of a colloid osmotic pressure. The distal tubule primarily reabsorbs and secretes ions. The intermediate tubule varies in function among vertebrate class. In Mammalia, it is termed the loop of Henle and 
serves a concentrating function. At the distal end of the distal tubule, the filtrate contains substances not reabsorbed and also those secreted. It flows into collecting tubules, and subsequently into the bladder. Vertebrate bladders differ tremendously. Birds and most reptiles do not store urine, while mammals have a thick muscular bladder which does, and voids it periodically. Amphibians possess a thin-walled bladder which in some species may hold fluid amounting to $50 \%$ of body weight (Bentley 1966). Their bladder also serves as a storage organ for water and salts which may be mobilized during dehydration (Ruibal 1962; Bentley 1966).

Glomerular filtration is the first mechanical step in the excretion of nitrogenous waste and osmoregulation. The rate of glomerular filtration (GFR) is under many influences. It is under the influence of hydrostatic pressures modulated by humoral (ionic) (Persson and Persson 1981), hormonal (Pang et al. 1980), and neural influences in the afferent and efferent arterioles (Morris and Gibbins 1983); capillary permeability; capillary surface area; net pressure (hydrostatic and colloid osmotic) gradient between the glomerular capillary and capsular space; glomerular blood flow; and the number of actively filtering glomeruli (Forster 1942). The net pressure gradient is a result of hydrostatic pressures in the glomerular bed and capsular space as well as colloid osmotic pressures in these two spaces. Afferent and efferent arterioles are subject to constriction and dilation, which, by altering vascular resistances, may affect plasma flow rates through the glomerulus, thus modifying GFR. Among other factors influencing GFR is regulation of the renal blood flow, by constriction/dilatation of afferent and efferent arterioles. GFR is modified by hormonal and neural factors affecting glomerular capillary pressure and/or 
changes in renal blood flow. If renal plasma flow increases, then GFR increases as a result of increasing glomerular hydrostatic pressure.

Dilatation of the afferent arteriole increases the hydrostatic pressure in the glomerulus which increases GFR. Constriction of the afferent arteriole decreases glomerular pressure, which decreases GFR. Constriction of the efferent arteriole increases GFR by increasing in glomerular pressure because of an increased resistance to blood flow from the glomerulus. If the constriction were severe, however, an overall decrease in GFR could occur because of reduced flow through the glomerulus.

Renal blood flow is also subject to an autoregulation feedback mechanism of its own termed "juxtaglomerular feedback". This feedback is mediated by tubule juxtaglomerular cells which respond to low ion concentrations in the luminal fluid. These low ion concentrations are the result of low GFR. Luminal fluid moves slowly, allowing for a relative greater amount of reabsorption, yielding lower concentrations in the filtrate. The low ion concentration has two similar vascular effects (Guyton 1991). One is dilation of the afferent arteriole, allowing an increase in GFR. In addition the low ionic concentration causes the release of renin and the subsequent actions of the renin-angiotensin system which ultimately constricts the efferent arteriole, also increasing GFR.

GFR is measured by measuring plasma and urine concentrations of a substance and the volume of urine produced over a time period in which the samples are taken. The substance must be completely filterable at the glomerulus and neither secreted nor absorbed by the tubules. Inulin, a polysaccharide of molecular weight 5200, filters across the glomerulus into Bowman's capsule without hindrance (Hendrix et al. 1937). As inulin is 
neither secreted or reabsorbed by the tubules, it is an ideal substance with which to measure GFR; the clearance of inulin is the same as the rate of glomerular filtration. Inulin has been established as a means of evaluating GFR (Hendrix et al. 1937) and is suitable for use in amphibians (Forster 1938).

Once filtered plasma enters the capsular lumen, it is called filtrate. The filtrate flows through the remainder of the nephron --the proximal, intermediate, distal tubules, and collecting ducts-- before flowing into the ureter as urine. Along the length of the tubule, reabsorption and secretion modify the filtrate. These processes are performed by the tubule epithelial cells and determine the final composition of ureteral urine. Nutrients such as glucose, amino acids, and vitamins, ions, and water are reabsorbed; metabolic end products such as urea are excreted. Absorptive processes include osmosis and primary and secondary active transport. Secretion is an active, energy-requiring process.

Reabsorption occurs mostly in the proximal tubule via active transport of sodium ions. Sodium accounts for over $90 \%$ of the osmotic pressure of plasma. It is so important in its osmotic role that regulation of intravascular sodium concentration directly affects blood volume. The reabsorption of sodium occurs via the operation of sodium-potassium pumps in the basolateral membrane of the tubule cells. By continually pumping sodium into the interstitium, these cells maintain a low intracellular concentration of sodium in addition to a negative intracellular potential. Studying Necturus and Amphiuma, several investigators (Maude et al. 1966; Sullivan 1968; Boulpaep 1971; Grandchamp and Boulpaep 1974) have demonstrated transepithelial potentials ranging from -6 to -45 
$\mathrm{mV}$ across proximal and distal tubular cell membranes. Not all tubule potentials are negative; Wilbrandt (1938) demonstrated an intermediate tubule potential of $+6 \mathrm{mV}$. The combination of low intracellular sodium concentration and the negative intracellular potential sets up a diffusion gradient for sodium from the luminal space into the intracellular space. As there are carrier proteins in the luminal membrane for sodium, this movement of sodium amounts to facilitated diffusion. The diffusion of sodium powers secondary active absorption, or "cotransport", of potassium, chloride (in mammalian intermediate portions), glucose, and amino acids. This process occurs in the proximal tubule via sodium carriers which cotransport glucose, amino acids, and potassium. As solutes move out of the luminal space, the filtrate becomes more dilute and increasing extratubular osmotic pressure facilitates a passive diffusion of water out of the tubule. In this way, the kidney conserves ions, nutrients, and water.

Secretion occurs mainly in the distal tubule. Among the substances secreted are ions of hydrogen, potassium, and urea. The mechanism is secondary active secretion, or "counter transport". As sodium is carried into the cell, the carrier is energized and pumps the other substance into the lumen.

Kidneys respond to changes in blood plasma volume in order to maintain an optimal blood volume. Responses to perturbations in blood fluid volume include pressure diuresis, volume receptor-antidiuretic hormone mechanism, aldosterone release, and the colloid osmotic pressure effect (Navar and Guyton 1975). Pressure diuresis is a mechanical process. As volume increases, arterial pressure increases, pressure in the afferent arteriole increases. This increased pressure drives more fluid across the 
glomerulus, increasing GFR. The increased GFR and filtrate flow rate, in conjunction with increased peritubular capillary pressure, diminishes tubular reabsorption, increasing UFR and thus correcting for the increase in blood fluid volume. Volume and osmotic receptors respond to increased fluid volumes via hormonal and neural reflexes. Volume receptors, also called baroreceptors, are located in the atria of the heart and respond to stretch by releasing atrial natriuretic factor (ANF) (Dietz 1984; Lang et al. 1987). ANF increases natriuresis and so decreases blood volume because of the additional water required to excrete the additional sodium. Other baroreceptors are present in the vasculature, notably the pulmocutaneous artery. They respond to increases in pressure by initiating neural mechanisms for peripheral vasodilatation (Ishii and Ishii 1978). The vasodilatation decreases pressure to appropriate physiological levels. Osmoreceptors in the hypothalamic region of the brain respond to reduced osmotic pressure by inhibiting the release of the amphibian antidiuretic hormone, arginine vasotocin (AVT), from the hypophysis. This inhibition of AV'T release has the effect of increasing urine production through diuresis (Sawyer 1951), returning blood volume to pre-perturbation levels. Aldosterone has not been shown to have any renal effects in amphibians (Bentley 1976). Its effects are on the skin and bladder, where it responds to low blood volume by increasing sodium transport into the blood (Bentley 1976). Starling forces at the capillaries also figure into the blood volume equation, as changes in volume directly affect the colloidal osmotic pressure of the blood. As blood volume increases, colloidal osmotic pressure decreases. This decrease facilitates an increase in glomerular filtration due to lowered plasma oncotic pressure. The decreased oncotic pressure in the 
capillaries also reduces tubular uptake, increasing urine production and reducing blood volume. 
MATERIALS AND METHODS

Toads were purchased from biological supply houses and maintained at $20^{\circ} \mathrm{C}$ in tilted plastic tubs with tap water at one end. No photoperiod was established and no food was given. Ten toads (121-393 grams, mean: 297 grams with a SE of 29 grams) were used.

Toads were anesthetized by immersion in tricaine methanesulfonate (MS 222) until the corneal reflex could no longer be demonstrated. The surgical procedure consisted of placing an occlusive cannula (PE 90, Clay Adams) posteriorly into the ventral abdominal vein (Hillman and Withers, 1988), for injection, infusion, and blood sampling, and catheterizing both ureters via the cloaca (Middler and Kleeman, 1973) in order to collect urine. Flared (with heat) PE 90 (Clay Adams) catheters were inserted to a distance of approximately 1 centimeter from the kidneys. Both catheters and cannulae were sutured to the skin with sutures. Cannulae were kept patent with heparinized $0.8 \%$ saline. Recuperation of at least 12 hours was allowed before the experiments were begun. The experimental model is presented in Figure 1.

From each of 10 toads, an initial blood sample of approximately 200 $\mu \mathrm{l}$ was collected in a $400 \mu \mathrm{l}$ polypropylene microcentrifuge tube (VWR Scientific); a capillary tube also was filled. Subsequently, two $\mathrm{ml}$ of 40 $\mathrm{mg} / \mathrm{ml}$ inulin (Sigma Chemical Company) in distilled $\mathrm{H}_{2} \mathrm{O}$ was injected into each toad and allowed to equilibrate for $2 \mathrm{~h}$ prior to trials. After $2 \mathrm{~h}$, animals were weighed, placed on a screen and covered with opaque plastic tubs to minimize disturbance. The screen allowed free access to cannulae and catheters with minimal disruption to the animal. A second blood sample and 


\begin{tabular}{|c|c|c|c|}
\hline $\begin{array}{c}\text { Independent } \\
\text { Variable }\end{array}$ & $\begin{array}{c}\text { Independent } \\
\text { Variable }\end{array}$ & Covariate & $\begin{array}{c}\text { Repeated Measures } \\
\text { of Renal Responses }\end{array}$ \\
\hline \hline Treatment & Sequence & Infusion Rate & $\begin{array}{c}\text { Time } \\
\text { (15 min intervals) }\end{array}$ \\
\hline $\begin{array}{c}0.4 \% \text { saline } \\
\text { infusion }\end{array}$ & $\begin{array}{c}\text { Toads \#1-5 - day 1 } \\
\text { Toads \#6-10 - day } 2\end{array}$ & $\begin{array}{c}10 \text { different } \\
\text { rates }\end{array}$ & 123456678 \\
\hline $\begin{array}{c}1.4 \% \text { saline } \\
\text { infusion }\end{array}$ & $\begin{array}{c}\text { Toads \#6-10 - day 1 } \\
\text { Toads \#1-5 - day 2 }\end{array}$ & $\begin{array}{c}\text { same 10 rates } \\
\text { as above }\end{array}$ & $\begin{array}{c}\text { same sampling } \\
\text { periods }\end{array}$ \\
\hline
\end{tabular}

Figure 1. Experimental model. The first two sampling periods (pre-infusion) were used to establish "control" values for measured parameters. Volume expansion was administered at $30 \mathrm{~min}$. Renal responses measured at time intervals were UFR; GFR; urine and plasma ion concentrations; and ion excretion rates. $\mathrm{N}=10$ toads.

capillary tube of blood were collected from each toad at this time and at 15 min intervals following for a time period of $120 \mathrm{~min}$ beginning with the second sample. Beginning also with the second sample, urine from each toad was collected in tared $12 \times 75 \mathrm{~mm}$ polypropylene test tubes (Elkay Products, Inc.) for $15 \mathrm{~min}$ intervals. At $30 \mathrm{~min}$, each toad's blood volume was expanded by $10 \%$ of its body mass with saline (either 0.4 or $1.4 \%$ saline) via infusion pump (Sage Instruments, model 341B) .

Treatment was randomized for each toad. On the first day following surgery, five of the animals $(n=5)$ received a hypoosmotic $(0.4 \% \mathrm{NaCl})$ blood volume expansion equal to $10 \%$ of body mass (HO group); on the second day this group received a hyperosmotic $(1.4 \% \mathrm{NaCl})$ blood volume expansion equal to $10 \%$ of body mass (HR group). This treatment sequence was reversed for the other of the animals. Infusion rates were converted to mass specific rates for each animal resulting in ten different infusion rates and varied from 4.0 to $20.6 \mathrm{ml} \mathrm{kg}^{-1} \mathrm{~min}^{-1}$. Blood samples were centrifuged (Beckman Microfuge B) for $4 \mathrm{~min}$ to separate plasma for inulin analysis and 
determination of ion concentrations. Inulin concentrations in urine and plasma were determined with the use of a spectrophotometer (Bausch and Lamb) via the colorimetric method introduced by Yatzidis (1976). Flame photometry (Instrumentation Laboratory Inc. model 143) was used for plasma and urine sodium and potassium concentration .

GFR was calculated as inulin clearance according to the equation GFR $=U V / P$, where $U$ is [inulin] urine, $V$ is volume of urine produced over the measured period, and $\mathrm{P}$ is [inulin]plasma. UFR was determined by weighing the collection tubes and subtracting the tare after urine collection, dividing by the appropriate time factor, and assuming urine density is $1 \mathrm{~g} / \mathrm{ml}$. In order to observe blood volume changes, hematocrits were recorded for each animal, at $15 \mathrm{~min}$ intervals over the same time period. Blood samples were centrifuged (Adams Autocrit Centrifuge) for $5 \mathrm{~min}$ before hematocrit readings were taken.

Statistical analyses were performed with Statistica/Mac (R3, part 1, StatSoft, Inc. Copyright 1992) on a Macintosh IIx computer. All values are mean \pm one SE. Analysis of covariance (ANCOVA) with repeated measures was used to evaluate the overall responses to treatment and investigate differences in those responses with respect to the treatment. In order to evaluate differences between two means at specific times, post hoc Tukey tests were used. Simple linear regression and multiple regression were employed to investigate relationships between variables. Means of pre-infusion values were compared using t-tests. Results are interpreted as statistically significant at an alpha level of 0.05 . With reference to the figures, saline infusion occurred at $t=0 \mathrm{~h}$; values indicated at $t=0 \mathrm{~h}$ are the pre-infusion values. 
RESULTS

\section{PRE-INFUSION COMPARISONS}

Results of two-tailed t-tests on the pre-infusion data confirm that the treatment group means did not differ significantly pre-infusion (Table I). In addition, the pre-infusion UFRs and GFRs were not mass dependent, and no significant correlation existed for either variable. The infusion sequence (day 1 or day 2) had no significant effect on pre-infusion rates of UFR or GFR.

TABLE I

COMPARISON OF PRE-INFUSION VALUES FOR RENAL FUNCTIONS

\begin{tabular}{|c|c|c|c|c|c|}
\hline & HO group & HR group & Both groups & $\mathrm{t}$ & $\mathrm{p}$ \\
\hline $\begin{array}{c}\text { UFR } \\
(\mathrm{ml} / \mathrm{kg} / \mathrm{hr})\end{array}$ & $\begin{array}{c}35.2 \pm 5.7 \\
(\mathrm{~N}=10)\end{array}$ & $\begin{array}{c}30.1 \pm 5.9 \\
(\mathrm{~N}=9)\end{array}$ & $\begin{array}{c}32.8 \pm 4.0 \\
(\mathrm{~N}=19)\end{array}$ & 1.14 & 0.29 \\
\hline $\begin{array}{c}\text { GFR } \\
(\mathrm{m} / \mathrm{kg} / \mathrm{hr})\end{array}$ & $\begin{array}{c}50.3 \pm 9.0 \\
(\mathrm{~N}=8)\end{array}$ & $\begin{array}{c}47.8 \pm 6.0 \\
(\mathrm{~N}=8)\end{array}$ & $\begin{array}{c}47.1 \pm 5.1 \\
(\mathrm{~N}=16)\end{array}$ & 0.28 & 0.79 \\
\hline $\begin{array}{c}{[\mathrm{Na}] \text { plasma }} \\
(\mathrm{mEq} / \mathrm{L})\end{array}$ & $\begin{array}{c}97.3 \pm 2.8 \\
(\mathrm{~N}=10)\end{array}$ & $\begin{array}{c}99.5 \pm 1.1 \\
(\mathrm{~N}=8)\end{array}$ & $\begin{array}{c}98.3 \pm 1.6 \\
(\mathrm{~N}=18)\end{array}$ & 0.02 & 0.98 \\
\hline $\begin{array}{c}{[\mathrm{K}] \mathrm{plasma}} \\
(\mathrm{mEq} / \mathrm{L})\end{array}$ & $\begin{array}{c}1.87 \pm 0.12 \\
(\mathrm{~N}=10)\end{array}$ & $\begin{array}{c}1.85 \pm 0.09 \\
(\mathrm{~N}=8)\end{array}$ & $\begin{array}{c}1.86 \pm 0.07 \\
(\mathrm{~N}=18)\end{array}$ & 0.48 & 0.65 \\
\hline $\begin{array}{c}{[\mathrm{Na}] \text { urine }} \\
(\mathrm{mEq} / \mathrm{L})\end{array}$ & $\begin{array}{c}11.3 \pm 2.5 \\
(\mathrm{~N}=10)\end{array}$ & $\begin{array}{c}7.1 \pm 1.1 \\
(\mathrm{~N}=7)\end{array}$ & $\begin{array}{c}9.6 \pm 1.6 \\
(\mathrm{~N}=17)\end{array}$ & 2.1 & 0.08 \\
\hline $\begin{array}{c}{[\mathrm{K}] \text { urine }} \\
(\mathrm{mEq} / \mathrm{L})\end{array}$ & $\begin{array}{c}0.37 \pm 0.05 \\
(\mathrm{~N}=9)\end{array}$ & $\begin{array}{c}0.39 \pm 0.05 \\
(\mathrm{~N}=6)\end{array}$ & $\begin{array}{c}0.38 \pm 0.03 \\
(\mathrm{~N}=15)\end{array}$ & 0.55 & 0.61 \\
\hline $\begin{array}{c}\text { Natriuresis } \\
(\mathrm{mEg} / \mathrm{kg} / \mathrm{hr})\end{array}$ & $\begin{array}{c}0.35 \pm 0.07 \\
(\mathrm{~N}=10)\end{array}$ & $\begin{array}{c}0.20 \pm 0.04 \\
(\mathrm{~N}=7)\end{array}$ & $\begin{array}{c}0.29 \pm 0.05 \\
(\mathrm{~N}=17)\end{array}$ & 2.1 & 0.08 \\
\hline $\begin{array}{c}\text { Kaliuresis } \\
(\mathrm{mEg} / \mathrm{kg} / \mathrm{hr})\end{array}$ & $\begin{array}{c}14.8 \pm 4.3 \\
(\mathrm{~N}=9)\end{array}$ & $\begin{array}{c}14.6 \pm 4.2 \\
(\mathrm{~N}=6)\end{array}$ & $\begin{array}{c}14.7 \pm 3.0 \\
(\mathrm{~N}=15)\end{array}$ & 1.5 & 0.19 \\
\hline $\begin{array}{c}\text { Hematocrit } \\
(\%)\end{array}$ & $\begin{array}{c}16.3 \pm 1.7 \\
(\mathrm{~N}=10)\end{array}$ & $\begin{array}{c}16.4 \pm 1.6 \\
(\mathrm{~N}=10)\end{array}$ & $\begin{array}{c}16.3 \pm 1.2 \\
(\mathrm{~N}=20)\end{array}$ & 0.08 & 0.94 \\
\hline
\end{tabular}




\section{HEMATOCRIT}

Hematocrits for both treatment groups showed an initial significant decrease (post hoc Tukey tests: HO, $16 \%$ to $13 \%, \mathrm{p}=0.002$; HR, $16 \%$ to $12 \%$, $\mathrm{p}=0.006$ ) which was maintained for the duration of the experiment (Figure 2). No significant difference in mean hematocrit between treatments was found.

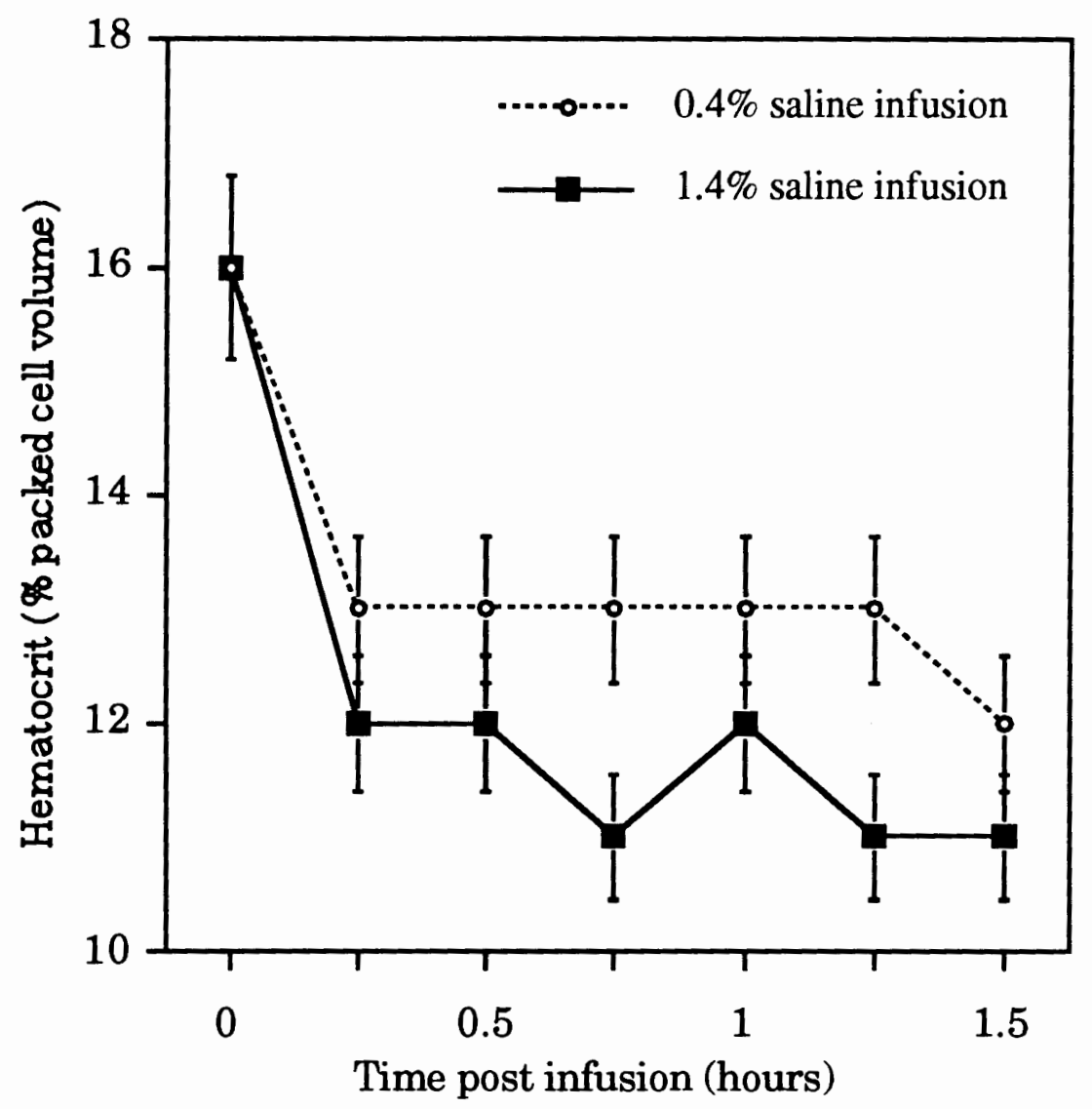

Figure 2. Effect of treatment on hematocrit. Values are means $\pm 1 \mathrm{SE}$. 
INFUSION RATE

Infusion rate was not significantly correlated with UFR; GFR; urine ion concentrations; or ion excretion rates during the infusion period when treatment groups were combined or partitioned (TABLE II).

TABLE II

CORRELATION COEFFICIENTS FOR INFUSION RATE AND RENAL RESPONSES DURING THE INFUSION PERIOD

\begin{tabular}{|c|c|c|c|c|c|c|}
\hline & $\begin{array}{c}\mathbf{r} \\
\text { HO } \\
\text { group }\end{array}$ & $\begin{array}{c}\mathrm{p} \\
\text { HO } \\
\text { group }\end{array}$ & $\begin{array}{c}\mathbf{r} \\
\mathrm{HR} \\
\text { group }\end{array}$ & $\begin{array}{c}\mathrm{p} \\
\text { HR } \\
\text { group }\end{array}$ & $\begin{array}{c}\mathbf{r} \\
\text { Both } \\
\text { groups }\end{array}$ & $\begin{array}{c}\mathrm{p} \\
\text { Both } \\
\text { groups }\end{array}$ \\
\hline UFR & -0.11 & 0.77 & -0.10 & 0.79 & -0.12 & 0.62 \\
& $\mathrm{~N}=10$ & & $\mathrm{~N}=9$ & & $\mathrm{~N}=19$ & \\
\hline GFR & -0.30 & 0.26 & -0.65 & 0.08 & 0.07 & 0.88 \\
& $\mathrm{~N}=8$ & & $\mathrm{~N}=8$ & & $\mathrm{~N}=16$ & \\
\hline Urine [Na] & 0.16 & 0.66 & 0.50 & 0.26 & 0.29 & .027 \\
& $\mathrm{~N}=10$ & & $\mathrm{~N}=7$ & & $\mathrm{~N}=17$ & \\
\hline Natriuresis & 0.28 & 0.43 & 0.62 & 0.14 & 0.032 & 0.21 \\
& $\mathrm{~N}=10$ & & $\mathrm{~N}=7$ & & $\mathrm{~N}=17$ & \\
\hline Urine [K] & 0.43 & 0.25 & 0.31 & 0.55 & 0.27 & 0.34 \\
& $\mathrm{~N}=9$ & & $\mathrm{~N}=6$ & & $\mathrm{~N}=15$ & \\
\hline Kaliuresis & 0.03 & 0.94 & 0.23 & 0.67 & 0.08 & 0.78 \\
& $\mathrm{~N}=9$ & & $\mathrm{~N}=6$ & & $\mathrm{~N}=15$ & \\
\hline
\end{tabular}

With two exceptions, over the duration of the experiment, infusion rate did not correlate with UFR or maximal UFR; GFR or maximal GFR; urine ion concentrations; natriuresis or kaliuresis when treatment groups were combined or when the data were partitioned into treatment groups (Table III). The correlations for GFR in the HO group and natriuresis in the HR group are significant but the coefficient is low. 
TABLE III

CORRELATION COEFFICIENTS FOR INFUSION RATE

AND RENAL RESPONSES POST

INFUSION PERIOD. ${ }^{*} \mathrm{p}<0.05$.

\begin{tabular}{|c|c|c|c|c|c|c|}
\hline & $\begin{array}{c}\mathbf{r} \\
\text { HO } \\
\text { group }\end{array}$ & $\begin{array}{c}\mathrm{p} \\
\text { HO } \\
\text { group }\end{array}$ & $\begin{array}{c}\mathbf{r} \\
\mathrm{HR} \\
\text { group }\end{array}$ & $\begin{array}{c}\mathrm{p} \\
\mathrm{HR} \\
\text { group }\end{array}$ & $\begin{array}{c}\mathrm{r} \\
\text { Both } \\
\text { groups }\end{array}$ & $\begin{array}{c}\mathrm{p} \\
\text { Both } \\
\text { groups }\end{array}$ \\
\hline UFR & $\begin{array}{c}0.25 \\
N=58\end{array}$ & 0.06 & $\begin{array}{c}0.01 \\
\mathrm{~N}=52\end{array}$ & 0.94 & $\begin{array}{c}0.17 \\
N=110\end{array}$ & 0.08 \\
\hline UFRmax & $\begin{array}{c}-0.38 \\
N=9\end{array}$ & 0.28 & $\begin{array}{c}-0.16 \\
N=10\end{array}$ & 0.70 & $\begin{array}{c}0.24 \\
\mathrm{~N}=19\end{array}$ & 0.33 \\
\hline GFR & $\begin{array}{l}-0.30^{*} \\
\mathrm{~N}=46\end{array}$ & $0.04^{*}$ & $\begin{array}{c}0.13 \\
\mathrm{~N}=46\end{array}$ & 0.38 & $\begin{array}{c}0.20 \\
\mathrm{~N}=92\end{array}$ & .052 \\
\hline GFRmax & $\begin{array}{l}0.59 \\
\mathrm{~N}=8\end{array}$ & 0.13 & $\begin{array}{l}0.05 \\
\mathrm{~N}=8\end{array}$ & 0.90 & $\begin{array}{l}-0.27 \\
\mathrm{~N}=16\end{array}$ & 0.30 \\
\hline Urine $[\mathrm{Na}]$ & $\begin{array}{c}0.09 \\
\mathrm{~N}=58\end{array}$ & 0.51 & $\begin{array}{c}0.08 \\
N=42\end{array}$ & 0.60 & $\begin{array}{c}0.08 \\
\mathrm{~N}=100\end{array}$ & 0.41 \\
\hline Natriuresis & $\begin{array}{c}0.10 \\
\mathrm{~N}=58\end{array}$ & 0.47 & $\begin{array}{l}0.34^{*} \\
\mathrm{~N}=42\end{array}$ & $0.03^{*}$ & $\begin{array}{c}0.01 \\
N=100\end{array}$ & 0.92 \\
\hline Urine $[\mathrm{K}]$ & $\begin{array}{c}0.22 \\
\mathrm{~N}=52\end{array}$ & 0.11 & $\begin{array}{c}0.03 \\
\mathrm{~N}=36\end{array}$ & 0.87 & $\begin{array}{c}0.06 \\
\mathrm{~N}=88\end{array}$ & 0.56 \\
\hline Kaliuresis & $\begin{array}{c}0.10 \\
\mathrm{~N}=52\end{array}$ & 0.46 & $\begin{array}{c}0.14 \\
\mathrm{~N}=36\end{array}$ & 0.42 & $\begin{array}{c}0.04 \\
\mathrm{~N}=88\end{array}$ & 0.74 \\
\hline
\end{tabular}

ELECTROLYTES

\section{Sodium Concentration In Plasma}

Sodium concentrations in plasma differed significantly $(\mathrm{p}=0.000001)$

between the HO and HR groups (Figure 3). The HR group showed an immediate and significant ( $\mathrm{p}=0.0001$, Tukey test) increase in plasma sodium concentration which did not diminish over the data collection period, thus providing a consistent osmotic stimulus to regulatory systems. Hypoosmotic treatment did not significantly affect plasma sodium concentrations relative to the pre-infusion concentration. 


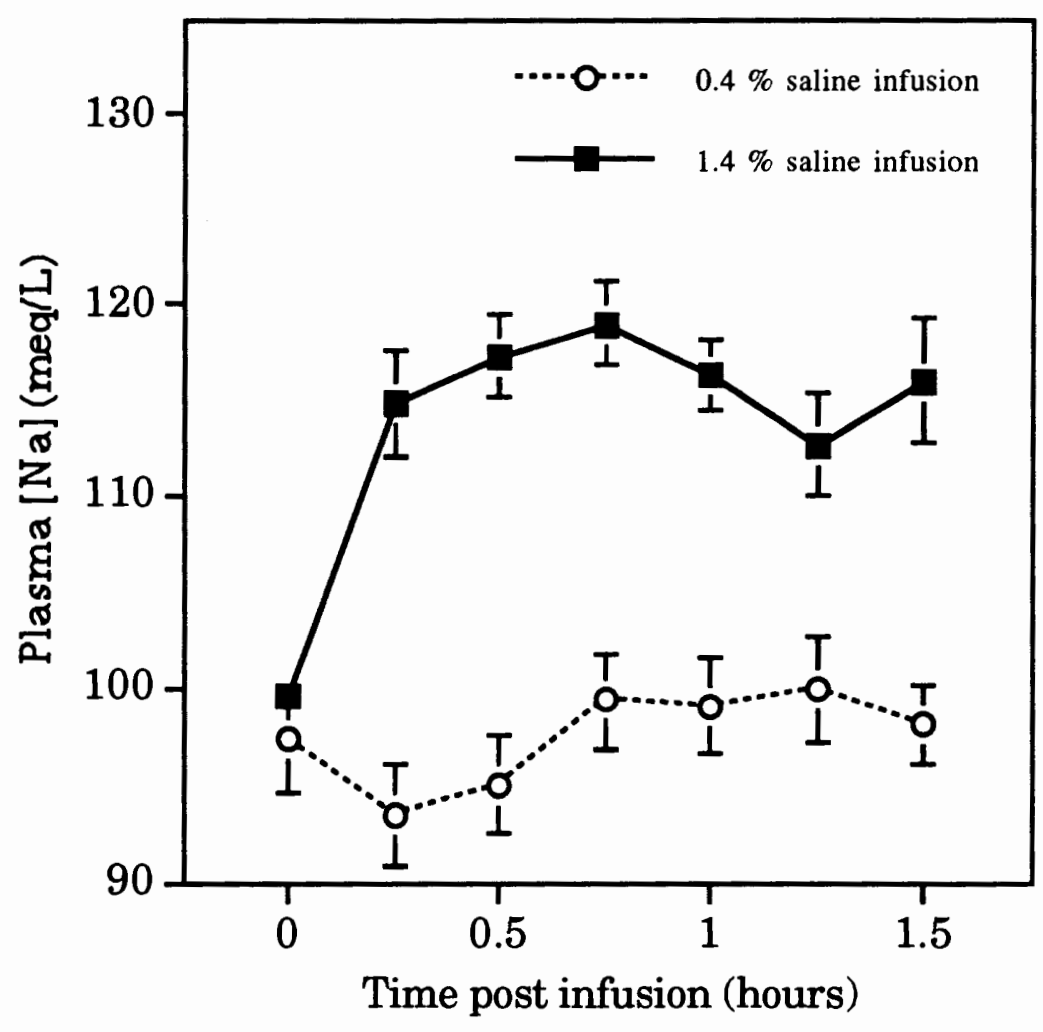

Figure 3. Effect of treatment on plasma sodium concentration. Values are means $\pm 1 \mathrm{SE}$.

\section{Sodium Concentration in Urine}

Sodium concentration in urine differed significantly $(p=0.00004)$ between the $\mathrm{HO}$ and HR groups (Figure 4). The HO group showed a peak forconcentration at $30 \mathrm{~min}$, after which it returned to pre-infusion values. 


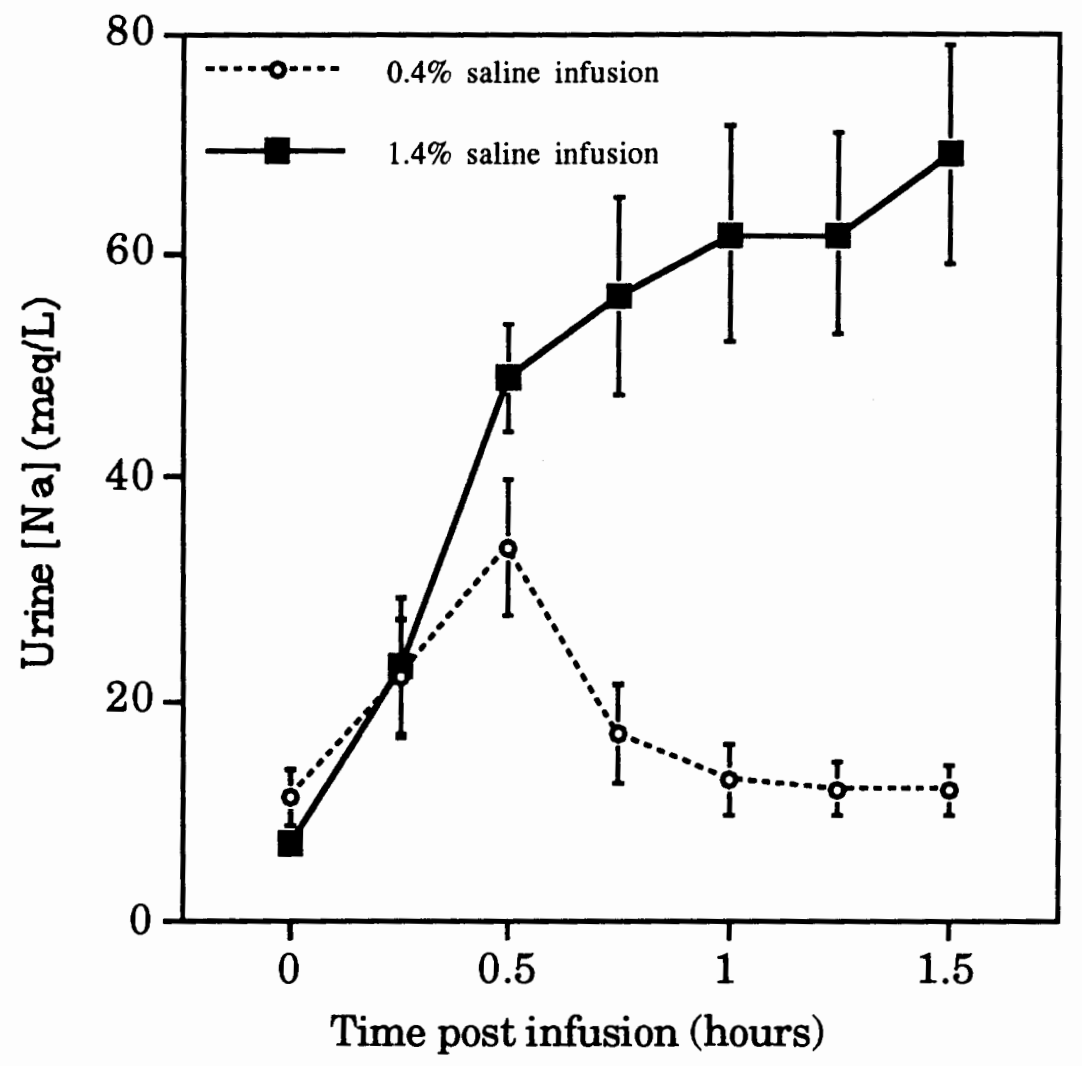

Figure 4. Effect of treatment on urine sodium concentration. Values are means $\pm 1 \mathrm{SE}$.

Post hoc results of urine sodium concentration relative to pre-infusion are in Table IV. Sodium concentration in urine of the HO group was not significantly different, with the exception $30 \mathrm{~min}$, from pre-infusion values; in the HR group sodium concentration in urine was significantly different from pre-infusion values at each time period (Table IV). 
TABLE IV

TUKEY TEST RESULTS OF URINE SODIUM CONCENTRATION RESPONSE RELATIVE TO PRE-INFUSION VALUES OF URINE SODIUM CONCENTRATION.

\begin{tabular}{|c|c|c|}
\hline $\begin{array}{c}\text { Time } \\
\text { post infusion }\end{array}$ & HO group & HR group \\
\hline \hline 0.25 hours & NS & 0.02 \\
\hline 0.5 & 0.0001 & 0.0001 \\
\hline 0.75 & $\mathrm{NS}$ & 0.0001 \\
\hline 1.0 & $\mathrm{NS}$ & 0.0001 \\
\hline 1.25 & $\mathrm{NS}$ & 0.0001 \\
\hline 1.5 & $\mathrm{NS}$ & 0.0001 \\
\hline
\end{tabular}

Considering both treatments, plasma sodium concentration was the factor most responsible for urine sodium concentration (Table V). Looking at the treatments separately however, UFR contributed most to urine sodium concentration for the HO treatment and plasma potassium concentration was the only significant variablefor the HR treatment. 
TABLE V

STANDARDIZED ( $\beta$ ) REGRESSION WEIGHTS OF INDEPENDENT

VARIABLES ON URINE SODIUM CONCENTRATION AND CORRESPONDING MULTIPLE CORRELATION

COEFFICIENTS ${ }^{*} p<0.05$

\begin{tabular}{|c|c|c|c|c|c|c|c|}
\hline & UFR & GFR & {$[\mathrm{Na}]$ plasma } & {$[\mathrm{K}]$ plasma } & $R$ & $p$ & $N$ \\
\hline HO & $0.88^{*}$ & -0.38 & $0.45^{*}$ & -0.12 & $0.69^{*}$ & 0.00002 & 46 \\
\hline HR & -0.19 & -0.27 & -0.04 & $-0.43^{*}$ & $0.60^{*}$ & 0.007 & 36 \\
\hline Both & 0.18 & -0.19 & $0.57^{*}$ & $-0.26^{*}$ & $0.68^{*}$ & 0.00001 & 82 \\
\hline
\end{tabular}

\section{Potassium Concentration in Plasma}

There was no significant $(p=0.22)$ difference between the $\mathrm{HO}$ and the HR groups (Figure 5). The HR treatment resulted in a significant ( $p=0.01$, Tukey test) decrease relative to pre-infusion values and remained significantly ( $p<0.02$, Tukey test) decreased until 60 min post infusion. Potassium concentration in plasma did not differ significantly from preinfusion concentration for the HO group. 


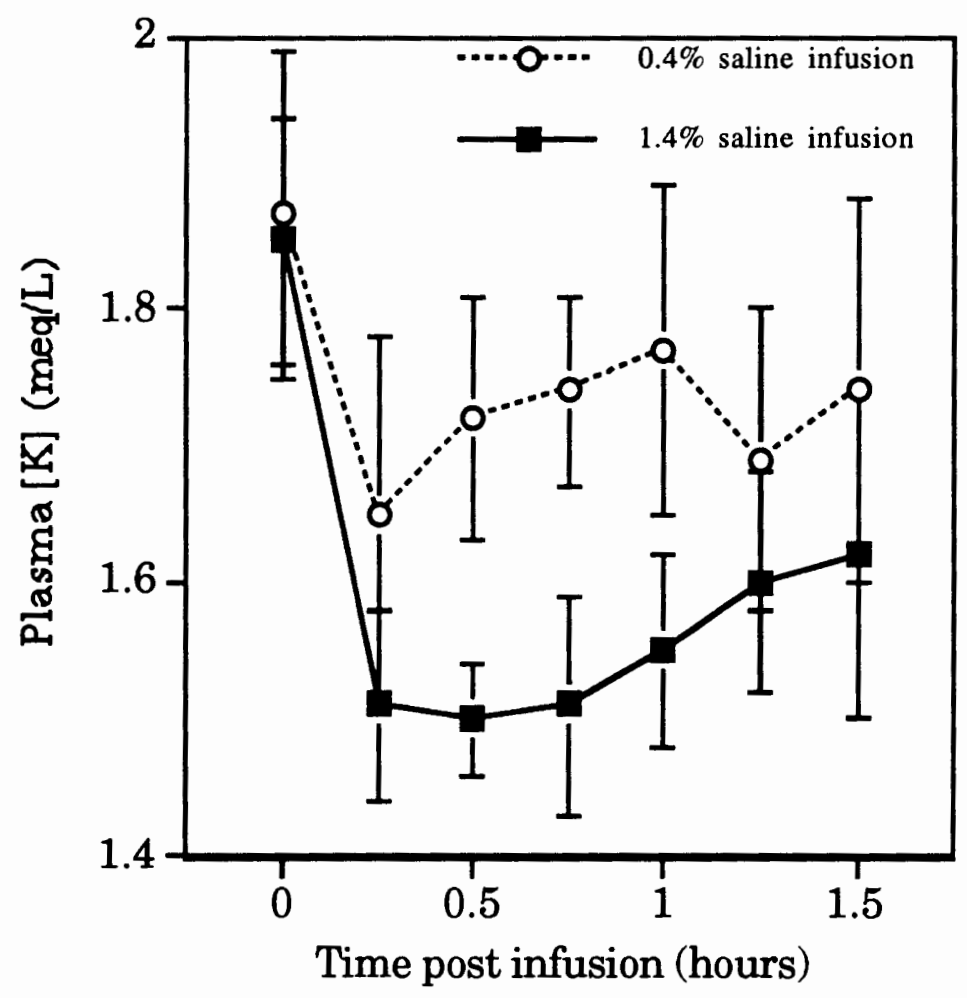

Figure 5. Effect of treatment on plasma potassium concentration. Values are means $\pm 1 \mathrm{SE}$.

\section{Potassium Concentration in Urine}

Urine potassium concentrations were significantly different $(p=0.003)$ between the $\mathrm{HO}$ and the $\mathrm{HR}$ groups, (Figure 6), with the HR group having higher potassium concentration in the urine than the HO group. Post hoc analyses showed in the $\mathrm{HO}$ group, at no time was the potassium concentration in urine significantly different from pre-infusion potassium concentration in urine. For the HR group, potassium concentration in the urine was only significantly different at $\mathrm{t}=90 \mathrm{~min}(\mathrm{p}=0.03)$. 


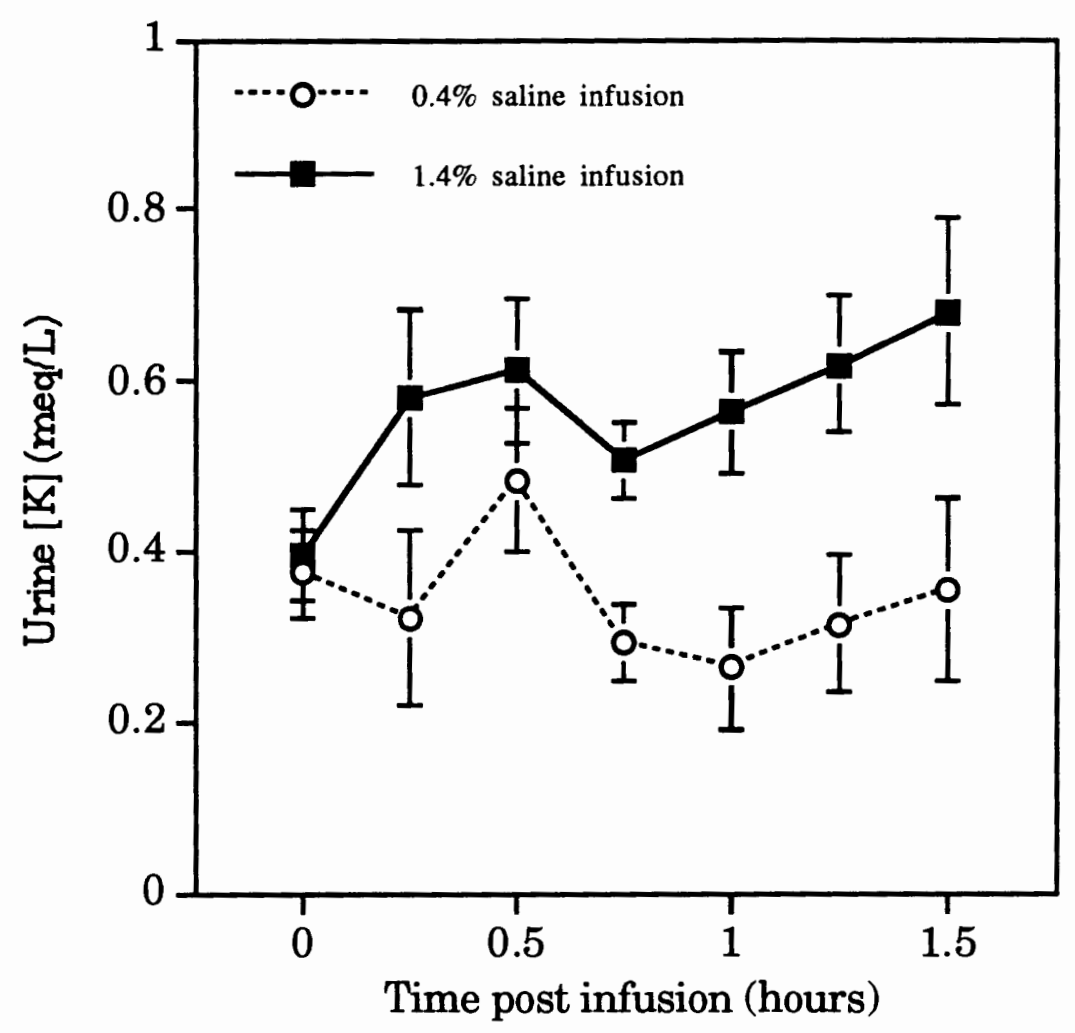

Figure 6. Effect of treatment on urine potassium concentration. Values are means $\pm 1 \mathrm{SE}$.

\section{UFR AND GFR}

\section{UFR}

UFR differed significantly ( $p=0.00002)$ between the HO and HR groups (Figure 7). The HO group produced significantly more urine at each sampling period. Post hoc analyses showed UFR in the HO group was significantly different from pre-infusion rates at $30 \mathrm{~min}(\mathrm{p}=0.0001) ; 75 \mathrm{~min}$ ( $p=0.03)$; and at $90 \mathrm{~min}(\mathrm{p}=0.001)$. In the HR group, all UFRs post $30 \mathrm{~min}$ post infusion were significantly different from pre-infusion UFR ( $\mathrm{p} \leq 0.013$ for each of these sampling periods). 


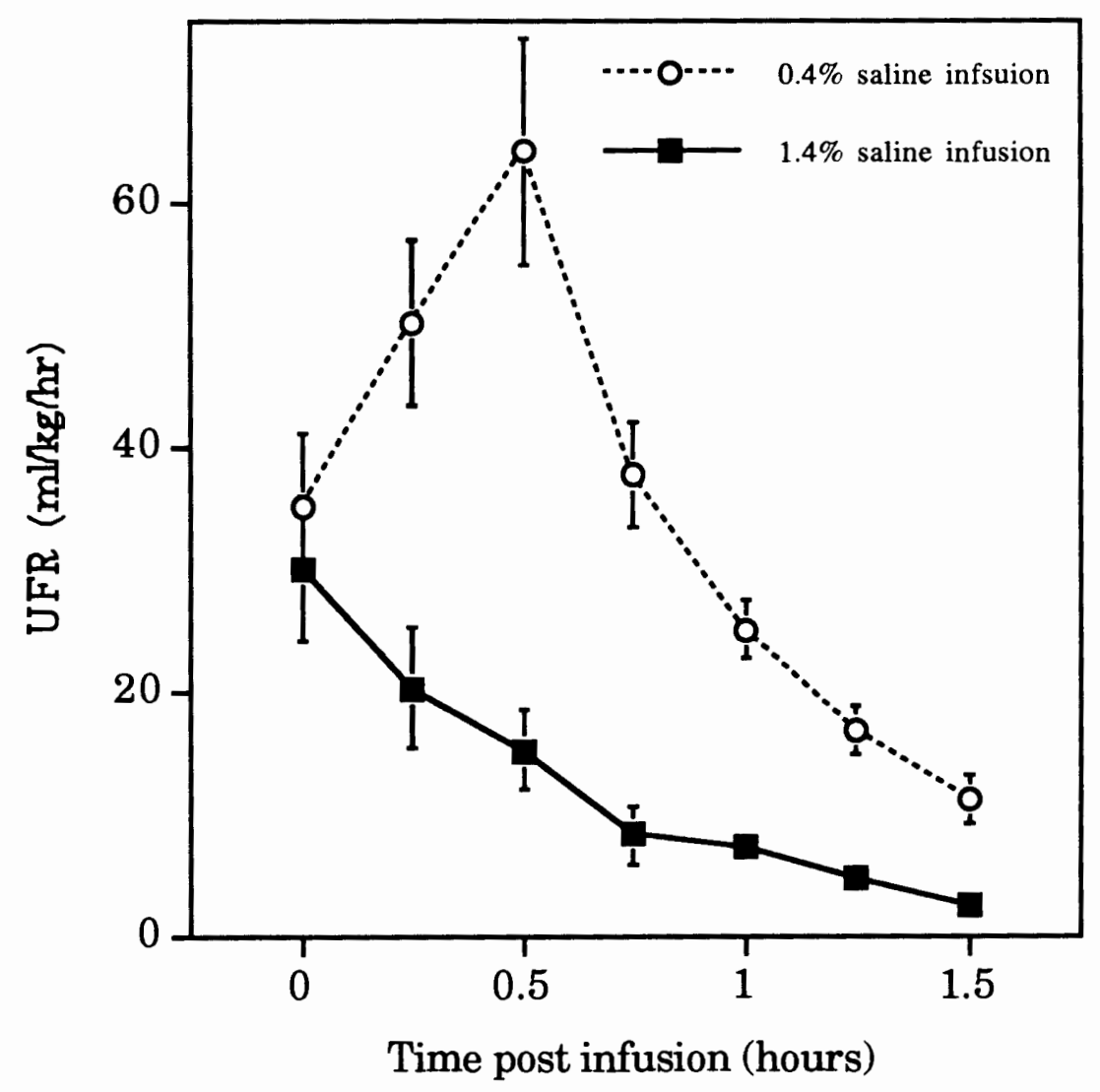

Figure 7. Effect of treatment on urine flow rate (UFR). Values are means $\pm 1 \mathrm{SE}$.

\section{GFR}

GFR differed significantly ( $p=0.01$ ) between $\mathrm{HO}$ and $\mathrm{HR}$ groups (Figure 8). Hypoosmotic infusions resulted in higher GFRs. Post hoc analysis demonstrated GFR was not significantly different $(p=0.8)$ between the $\mathrm{HO}$ and HR groups at $15 \mathrm{~min}$. The overall difference manifested itself at $30 \mathrm{~min}$, for which the post hoc analysis yielded a significant difference $(\mathrm{p}=$ $0.01)$. GFR of the HO group was significantly different $(\mathrm{p}=0.008)$ from preinfusion HO GFR only at $90 \mathrm{~min}$. GFR of the HR group was significantly 
different ( $p \leq 0.047)$ from pre-infusion GFR at each sampling period post 30 min infusion.

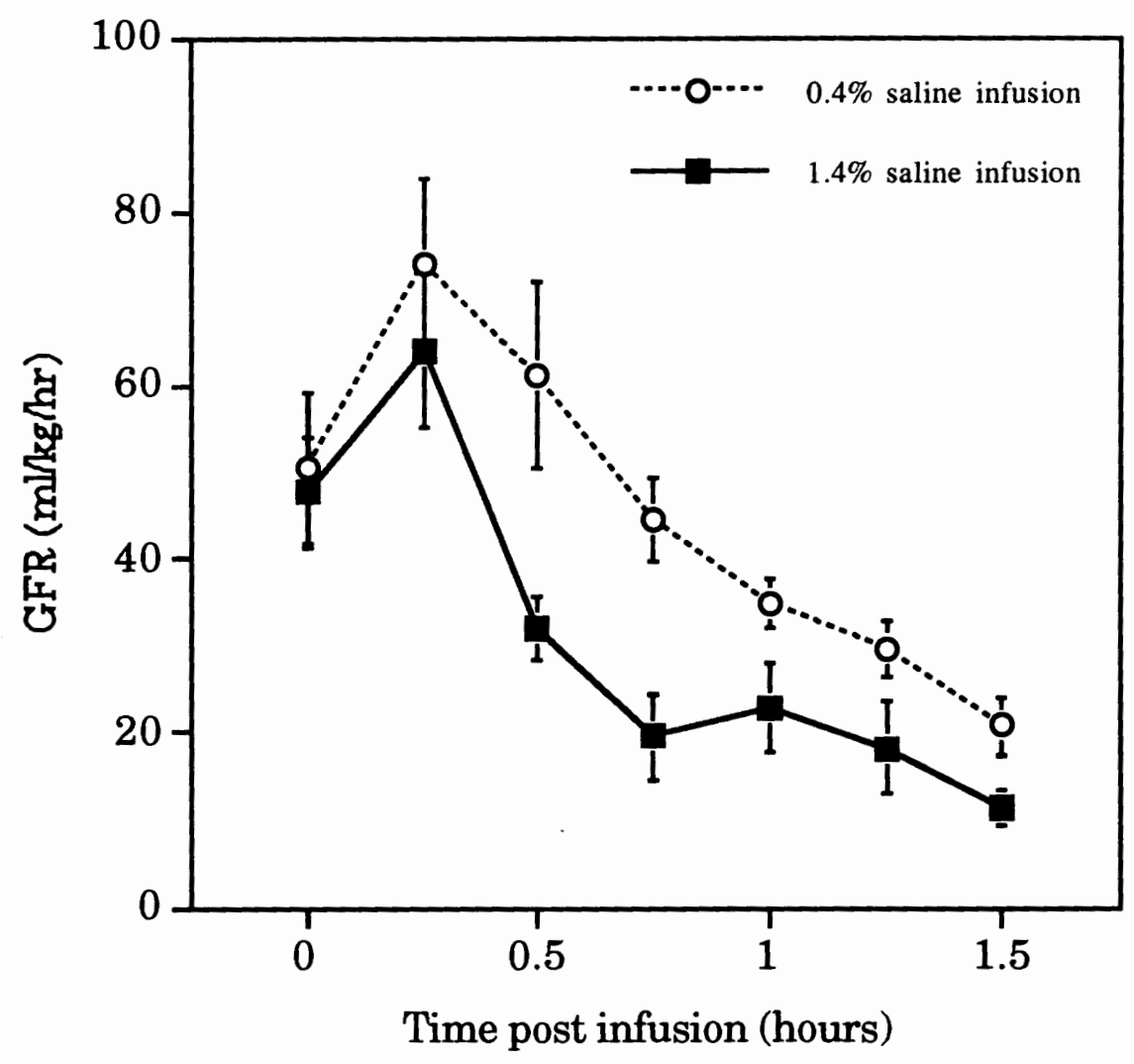

Figure 8. Effect of treatment on glomerular filtration rate (GFR). Values are means $\pm 1 \mathrm{SE}$.

\section{UFR, GFR, and Ion Concentrations}

Considering both treatments together, a significant correlation between UFR and GFR was found ( $r=0.88, p<0.000001$; Figure 9). 


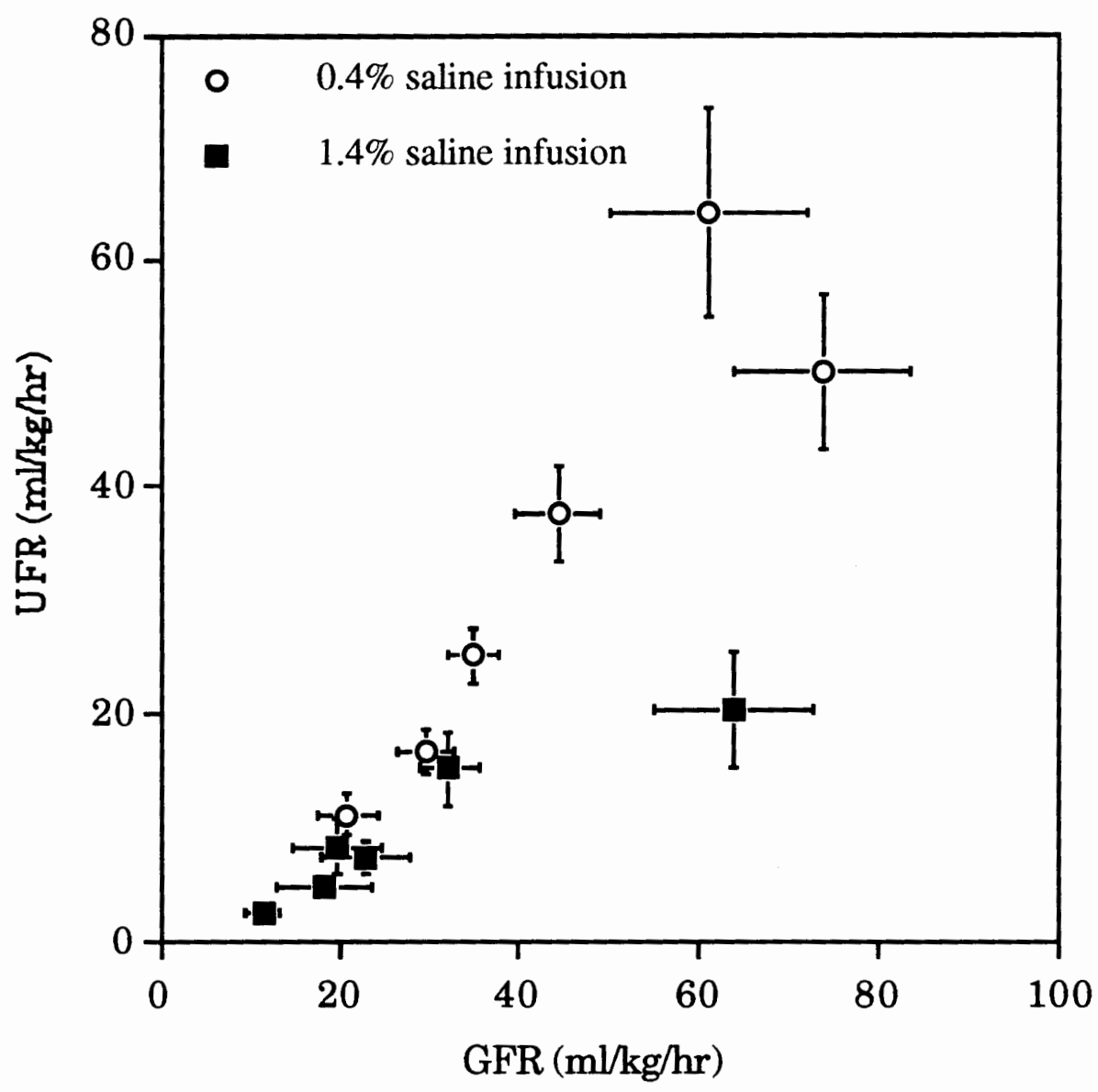

Figure 9. Correlation of UFR and GFR. Error bars represent $\pm 1 \mathrm{SE}$.

Table VI contains the regression results with treatments separated. Regression equations for the groups are: HO group: UFR $=-6.5+0.9 * \mathrm{GFR}$; HR group: UFR $=-0.05+0.37 *$ GFR . 
TABLE VI

CORRELATION COEFFICIENTS OF UFR AND GFR.

\begin{tabular}{|c|c|c|c|}
\hline & $\mathrm{r}$ & $\mathrm{p}$ & $\mathrm{N}$ \\
\hline HO & $0.90^{*}$ & 0.000001 & 46 \\
\hline HR & $0.82^{*}$ & 0.000001 & 46 \\
\hline Both & $0.88^{*}$ & 0.000001 & 92 \\
\hline
\end{tabular}

Additionally, UFR was correlated with GFR, plasma sodium and potassium concentrations (Table VII).

TABLE VII

STANDARDIZED (b) REGRESSION WEIGHTS OF INDEPENDENT

VARIABLES ON UFR AND CORRESPONDING MULTIPLE CORRELATION COEFFICIENTS. ${ }^{*} \mathrm{p}<0.05$

\begin{tabular}{|c|c|c|c|c|c|c|}
\hline & GFR & $\begin{array}{c}{[\mathrm{Na}] \text { plasm }} \\
\mathrm{a}\end{array}$ & {$[\mathrm{K}]$ plasma } & $\mathrm{R}$ & $\mathrm{p},<$ & $\mathrm{N}$ \\
\hline HO & $0.87^{*}$ & -0.06 & -0.12 & $0.91^{*}$ & 0.0001 & 46 \\
\hline HR & $0.84^{*}$ & 0.10 & 0.06 & $0.84^{*}$ & 0.0001 & 36 \\
\hline Both & $0.80^{*}$ & $-0.2^{*}$ & -0.05 & $0.90^{*}$ & 0.0001 & 82 \\
\hline
\end{tabular}

Urine sodium concentration for both groups was correlated with UFR, GFR, and plasma sodium and potassium concentrations $(R=0.68, p<0.0001$; Table V). Additionally, urine sodium concentration was regressed on UFR (HO group, $r=0.49, p=0.0001, N=58 ;$ HR group, $r=0.41, p=0.007, N=42$;

Figure 10). The regression equations are: $\mathrm{HO}$ group: urine $[\mathrm{Na}]=6.9+$ $0.35 * U F R ;$ HR group: urine[Na] $=64.4-1.13 * U F R$. 


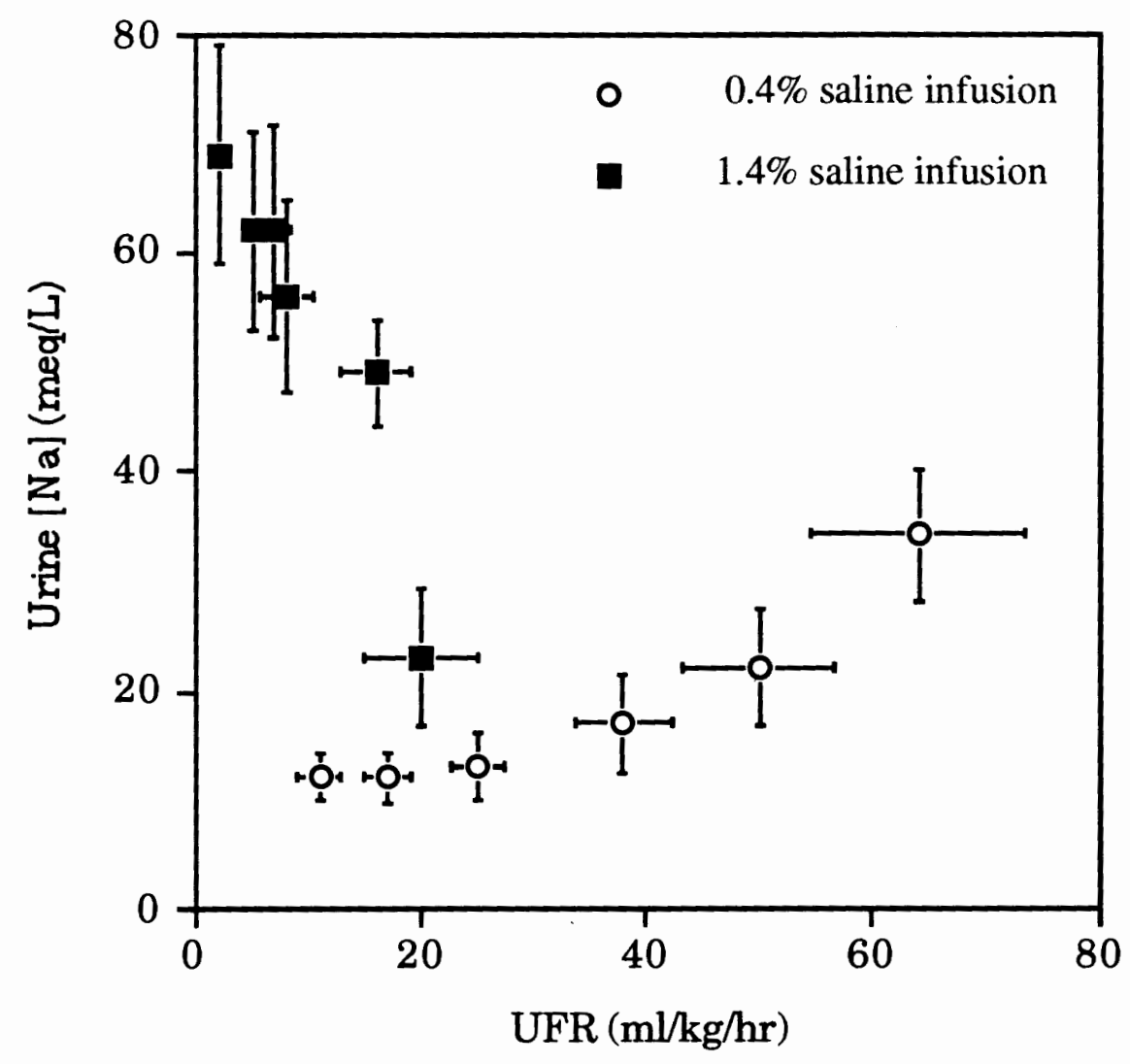

Figure 10. Correlation of UFR and urine sodium concentration. Error bars represent $\pm 1 \mathrm{SE}$.

Urine potassium concentration was correlated with UFR, GFR, plasma sodium and potassium concentrations (Table VIII). In addition, urine potassium concentration was regressed on UFR (HO group, $r=0.10$, $p=0.47, N=52 ;$ HR group, $r=0.01, p=0.94, N=36$; Figure 11 ). The regression equations are $\mathrm{HO}$ group: urine $[\mathrm{K}]=0.3+0.0006$ (UFR); HR group: urine $[\mathrm{K}]$ $=0.6-0.004$ (UFR). 
TABLE VIII

STANDARDIZED (b) REGRESSION WEIGHTS OF INDEPENDENT

VARIABLES ON URINE POTASSIUM CONCENTRATION AND CORRESPONDING MULTIPLE CORRELATION

COEFFICIENTS. ${ }^{*} \mathrm{p}<0.05$

\begin{tabular}{|c|c|c|c|c|c|c|c|}
\hline & UFR & GFR & {$[\mathrm{Na}]_{\text {plasma }}$} & {$[\mathrm{K}]$ plasma } & $\mathrm{R}$ & $\mathrm{p}$ & $\mathrm{N}$ \\
\hline HO & 0.19 & 0.03 & 0.003 & -0.09 & 0.24 & $\mathrm{NS}$ & 40 \\
\hline HR & -0.50 & 0.49 & -0.32 & $0.48^{*}$ & $0.56^{*}$ & 0.046 & 30 \\
\hline Both & -0.29 & 0.32 & $0.49^{*}$ & -0.03 & $0.54^{*}$ & 0.0001 & 70 \\
\hline
\end{tabular}

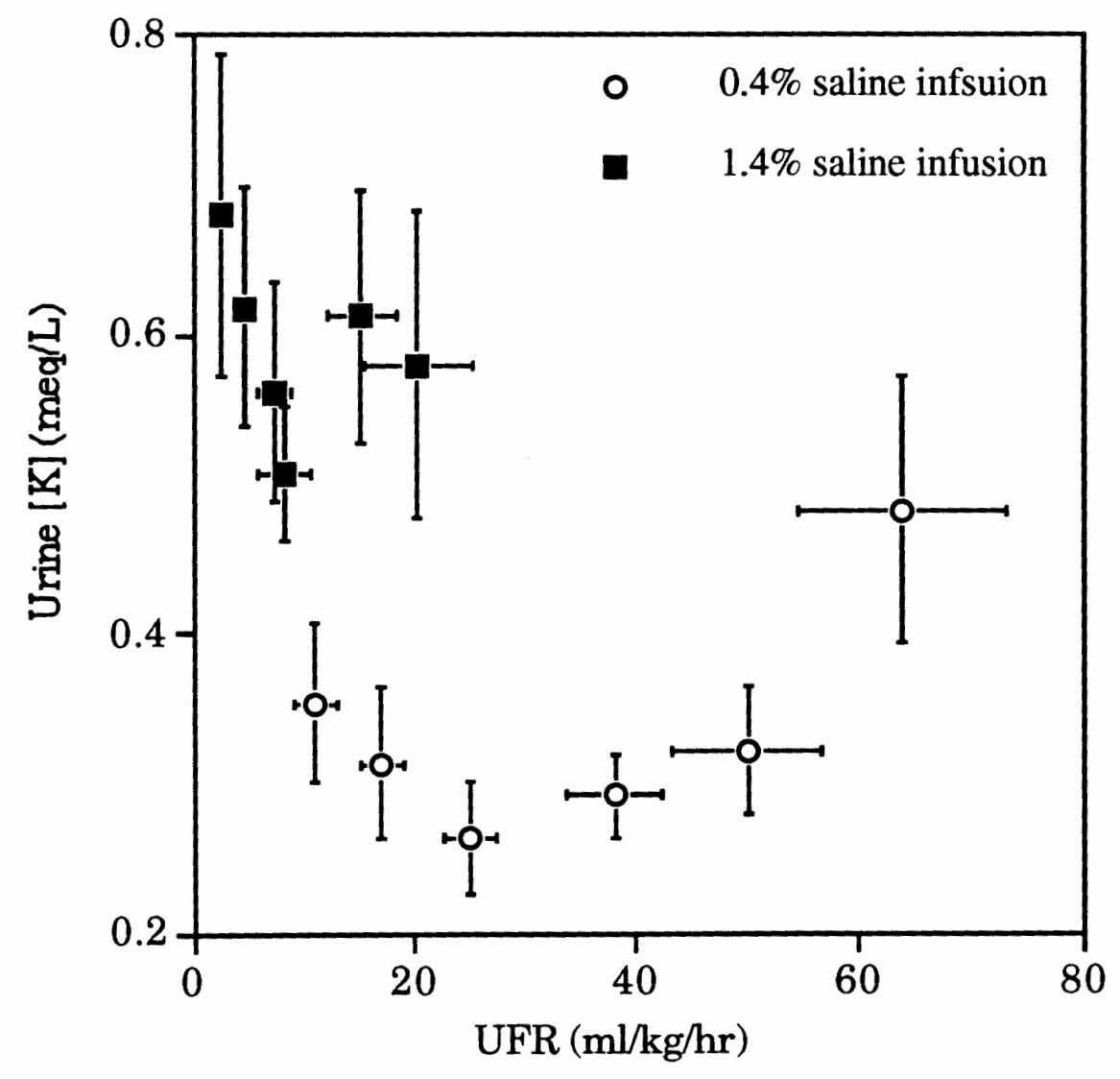

Figure 11. Correlation of UFR and urine potassium concentration. Error bars represent $\pm 1 \mathrm{SE}$. 
ION EXCRETION

\section{$\underline{\text { Natriuresis }}$}

Between the treatment groups, natriuresis did not differ significantly $(\mathrm{p}=0.07)$ after $90 \mathrm{~min}$, but did differ significantly over the first $60 \mathrm{~min}$ $(\mathrm{p}=0.04$; Figure 12). Post hoc analysis revealed a significant difference ( $p=0.0001$ ) between natriuresis of the $\mathrm{HO}$ and $\mathrm{HR}$ groups at 30 min post infusion; natriuresis of the HO group was significantly different ( $p=0.0001$ ) from pre-infusion natriuresis at $30 \mathrm{~min}$; the $\mathrm{HR}$ group did not significantly differ from pre-infusion natriuresis during any sampling period.

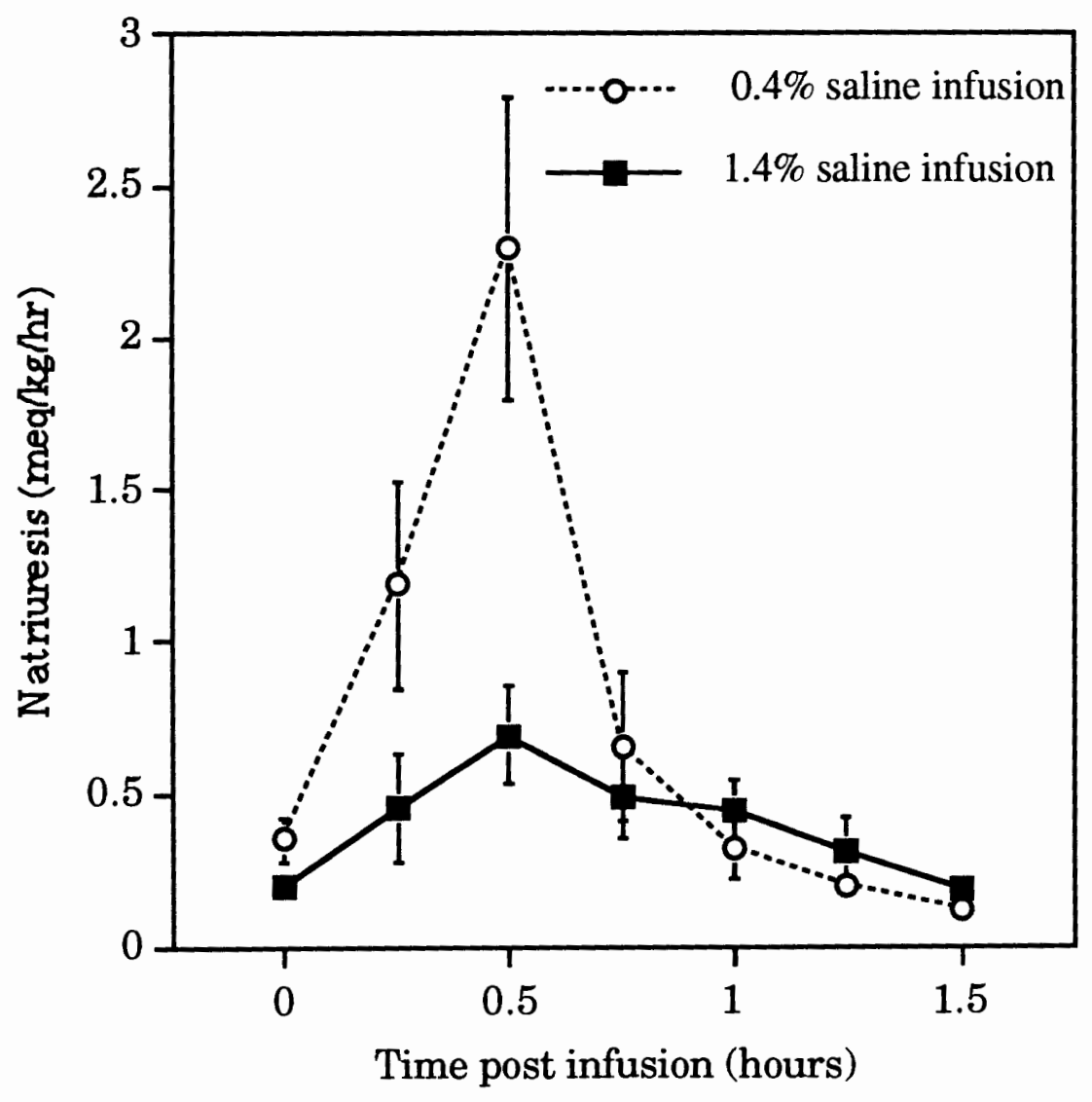

Figure 12. Effect of treatment on natriuresis. Values are means $\pm 1 \mathrm{SE}$. 
Natriuresis was correlated with UFR, GFR, urine sodium and potassium concentrations, and plasma sodium and potassium concentrations for both treatments (Table IX). The only significant independent variables were UFR and urine sodium concentration.

\section{TABLE IX}

STANDARDIZED (b) REGRESSION WEIGHTS OF INDEPENDENT VARIABLES ON NATRIURESIS AND CORRESPONDING MULTIPLE CORRELATION COEFFICIENTS ${ }^{*} p<0.05$

\begin{tabular}{|c|c|c|c|c|c|c|c|c|c|}
\hline & UFR & GFR & {$[\text { Na }]_{\text {urine }}$} & {$[\mathrm{K}]$ urine } & {$[\mathrm{Na}] \mathrm{pl}$} & {$[\mathrm{K}] \mathrm{pl}$} & $\mathrm{R}$ & $\mathrm{p},<$ & $\mathrm{N}$ \\
\hline HO & $0.55^{*}$ & -0.22 & $0.74^{*}$ & $0.10^{*}$ & -0.07 & 0.05 & $0.97^{*}$ & 0.01 & 40 \\
\hline HR & $0.79^{*}$ & 0.08 & $0.57^{*}$ & 0.02 & -0.01 & 0.02 & $0.86^{*}$ & 0.01 & 30 \\
\hline Both & $0.97^{*}$ & -0.24 & $0.59^{*}$ & 0.05 & -0.02 & -0.02 & $0.85^{*}$ & 0.01 & 70 \\
\hline
\end{tabular}

\section{Kaliuresis}

Kaliuresis was not significantly different between the $\mathrm{HO}$ and $\mathrm{HR}$ groups ( $\mathrm{p}=0.13$ ). Post hoc analysis demonstrates significantly different $(p=0.006)$ values for kaliuresis between treatments at $30 \mathrm{~min}$ (Figure 13); kaliuresis at $30 \mathrm{~min}$ in the $\mathrm{HO}$ group differed significantly $(\mathrm{p}=0.02)$ from preinfusion kaliuresis; kaliuresis in the HR group did not differ significantly from pre-infusion kaliuresis. 


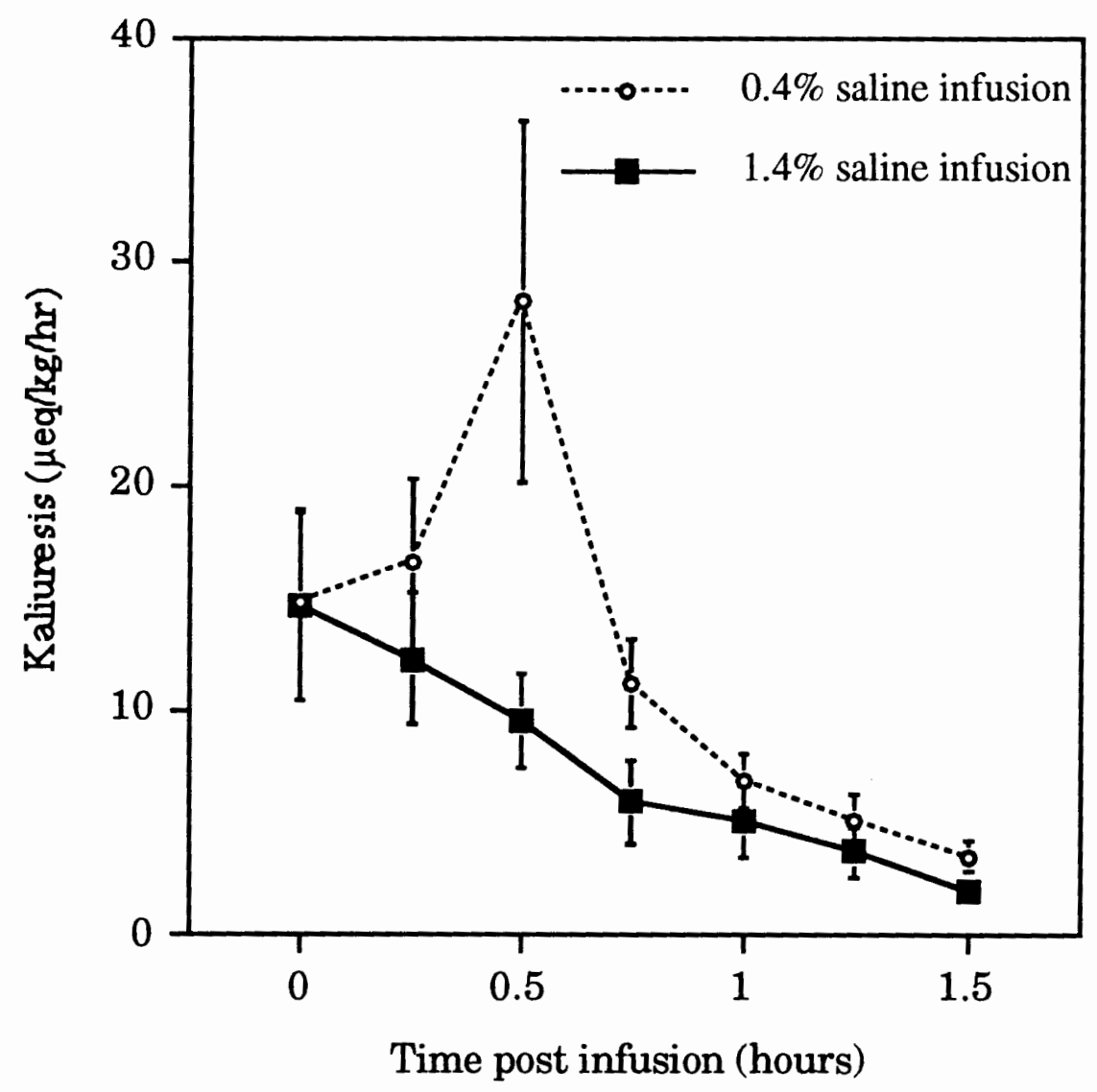

Figure 13. Effect of treatment on kaliuresis. Values are means \pm 1 S.E.

Kaliuresis was correlated with UFR, GFR, urine sodium and potassium concentrations, and plasma sodium and potassium concentrations (Table X). 
TABLE X

STANDARDIZED (b) REGRESSION WEIGHTS OF INDEPENDENT VARIABLES ON KALIURESIS AND CORRESPONDING MULTIPLE CORRELATION COEFFICIENTS. ${ }^{*} \mathrm{p}<0.05$

\begin{tabular}{|c|c|c|c|c|c|c|c|c|c|}
\hline & UFR & GFR & {$[\mathrm{Na}]$ urine } & {$[\mathrm{K}]$ urine } & {$[\mathrm{Na}] \mathrm{pl}$} & {$[\mathrm{K}] \mathrm{pl}$} & $\mathrm{R}$ & $\mathrm{p},<$ & $\mathrm{N}$ \\
\hline HO & $0.67^{*}$ & -0.11 & $0.16^{*}$ & $0.34^{*}$ & 0.05 & $0.08^{*}$ & $0.98^{*}$ & 0.01 & 40 \\
\hline HR & $0.88^{*}$ & 0.07 & -0.04 & $0.35^{*}$ & -0.02 & -0.10 & $0.97^{*}$ & 0.01 & 30 \\
\hline Both & $0.89^{*}$ & -0.09 & 0.08 & $0.32^{*}$ & 0.03 & 0.03 & $0.94^{*}$ & 0.01 & 70 \\
\hline
\end{tabular}




\section{DISCUSSION}

\section{HEMATOCRIT}

As hematocrit was not significantly different with respect to the treatment, the increase of the plasma volume was consistent with respect to the treatment groups.

\section{INFUSION RATE}

An important finding was for the most part UFRs, GFRs, ion concentrations, and excretion rates were not correlated with infusion rate, either during the infusion or the $90 \mathrm{~min}$ following. Renal negative feedback systems were insensitive to rate of blood volume expansion. The two exceptions of significant correlations had coefficients that were low; in each case infusion rate accounted for less than $10 \%$ of the variation in the dependent variable (Table III). Given the fact that 36 comparisons were made, chance alone would have predicted that at least one if not two correlations were significant. Overall, greater UFRs and GFRs at high infusion rates and lower rates at lower infusion rates were expected. Arterial blood pressure may be responsible for increases in GFR if these increases are transmitted to glomerular beds. In B. marinus arterial blood pressure does not increase (in fact it decreases slightly) with a $10 \%$ mass iso- or hyperosmotic expansion via ventral abdominal venous cannulae at rates that would translate to 5 to $25 \mathrm{ml} \mathrm{kg}^{-1} \mathrm{hr}^{-1}$ (Hillman, pers. comm.). These rates are similar in magnitude to those used in this experiment. Thus, for the present data, blood pressure increases may be dismissed as a potential factor responsible for increases in glomerular filtration rate. 
UFR and GFR

\section{$\underline{\text { UFR }}$}

UFR differed significantly between the $\mathrm{HO}$ and $\mathrm{HR}$ groups. A strong antidiuresis was observed in the HR group, as was observed by Hillman and Schimpf (1994) in B. marinus and Stiffler et al. (1982) in Ambystoma tigrinum, when using a $10 \%$ body weight hyperosmotic volume expansion. The HR group, which received a hyperosmotic as well as volume stimulus, responded to the osmotic stimulus preferentially, decreasing urine output immediately (Figure 7) while increasing urine sodium concentration (Figure 4). The volume stimulus was present for both treatments, so the antidiuresis is the result of increased osmotic concentration of the plasma. Animals that received the $\mathrm{HO}$ volume expansion responded with a marked diuresis, an effect also observed by Hillman and Schimpf (1994). The difference in UFR between the groups is predominantly accounted for by increased tubular reabsorption in the HR group, as there was only a slight difference in GFR response relative to treatment (Figure 8). The strong difference in UFR indicates that the HR group reabsorbed relatively large amounts of water in order to affect the antidiuresis. This antidiuretic response is similar to the decreased urine flow observed in animals removed from water (Tufts and Toews 1986). This is due to the osmotic-stimulated release of antidiuretic neurohypophyseal hormone, arginine vasotocin, AVT (Levinsky and Sawyer 1953; Bentley 1969) The effect of AVT is reduction of GFR via (1) vasoconstriction of the afferent arterioles (Richards and Schmidt 1924; Sawyer, 1951; Pang et al., 1980), and (2) increased tubular reabsorption of water in the tubules (Sawyer 1957). 
It is interesting to note that Hillman and Schimpf (1994) observed an increase in UFR with an isosmotic (0.8\% saline) $10 \%$ mass expansion, although not to the degree they observed with hypoosmotic expansion. This indicates that at this level of osmotic stimulation, the animal will excrete some of the excess water.

GFR

Uranga (1963) and Sawyer (1957) demonstrated a positive correlation between plasma volume and GFR in Bufo arenarum The current data show a similar GFR response to plasma volume expansion; in all cases for both treatments, GFR initially increased.

Though ANCOVA indicates significant differences for GFR, the overall response was fundamentally similar, and post hoc analyses demonstrated GFRs were significantly different at 30 and 45 minutes postinfusion (Figure 8). GFR in vertebrates is regulated by vasomotor tone of the afferent and efferent arterioles. In addition, it has been shown that amphibians may vary the number of individual glomeruli functioning at any one moment (Richards and Schmidt 1924; Forster 1942; and SchmidtNielsen and Forster 1954). These investigators all demonstrated that amphibians vary the number of active glomeruli participating in plasma ultrafiltration. An increased plasma volume may elicit this response. In fact, Uranga (1965) showed that $1 \%$ increase in plasma volume results in an increase in renal plasma flow in Bufo arenarum without accompanying increases in arterial blood pressure. Increases in arterial blood pressure are prevented through the feedback of arterial baroreceptors. Increases in pressure are sensed by baroreceptors in the pulmocutaneous artery (Van Vliet and West 1986a). Feed back to peripheral vasculature via the 
recurrent laryngeal nerve causes a decrease in systemic resistance (Ishii and Ishii 1978; Van Vliet and West 1986b) to accommodate the increase in arterial pressure. An increase in renal plasma flow without a concurrent rise in arterial pressure would necessitate either an increase in the number of active glomeruli or a decrease in renal vessel resistance in the beds already open. Pressure in the renal circuit would be maintained (i.e., not increase) because of the decrease in overall renal resistance when the additional glomerular beds open or, for the second case, as vasorelaxation occurs. The effect this decrease in renal resistance has on total peripheral resistance and arterial pressure is not clear. It appears that additional factors account for the lack of increase in arterial pressure, since the glomerular capillary beds are a small portion of the entire systemic capillary system, and thus account for a relatively small fraction of total peripheral resistance.

A difference in GFR response was not observed until 30-45 minutes post infusion. Persson and Persson (1981) discussed a tubuloglomerular feedback mechanism in nephrons of Amphiuma where an increase in GFR results in an increase in luminal chloride concentration. This chloride increase is sensed by distal tubule cells (Persson and Marsh 1987) and elicits a negative feedback vasoconstriction response on the afferent arteriole, decreasing GFR (Persson and Persson 1981). The mechanism employed by tubuloglomerular feedback is a possible explanation of the observed difference in GFR. As the plasma of the HR group has a significantly higher sodium chloride concentration, more $\mathrm{NaCl}$ is filtered. Subsequently, the relative increase in distal delivery of $\mathrm{NaCl}$ may be sufficient to decrease GFR relative to the $\mathrm{HO}$ treatment. 
Values observed for UFR were correlated with observed GFR values; $77 \%$ of the variation in UFR was due to GFR. To a large extent, glomerular activity determined the urine volume produced by the animal. Tubules were not effective at significantly altering this parameter when GFR was low. At lower GFR values, the correlation is stronger (Figure 9) than at higher GFRs where there is a divergence of the values of UFR between groups for similar GFRs. The data show that UFR between groups was significantly different and the overall GFR between groups was similar. This indicates at high GFRs, the difference in urine production between the groups is a result of tubular reabsorption. The present data are in agreement with SchmidtNielsen and Forster (1954), who determined diuresis is correlated with an increase in GFR and a decrease in tubular reabsorption.

The correlation between these two variables was tighter for the HO group ( $r=0.90)$ as compared to the HR treatment $(r=0.82)$. This supports the assertion, made above for the HR group, that the increased osmotic pressure of the filtrate feeds back to depress GFR. It naturally follows that the hypoosmotic group had a GFR that was more indicative of UFR.

\section{ELECTROLYTES}

Urine electrolyte concentration is a net result of: (1) the amount filtered into Bowman's capsule space--a direct consequence of plasma concentration; (2) tubular processes of reabsorption and secretion; and (3) rate of flow of tubular filtrate.

Volume expansions of either hypo- or hyperosmotic nature present fluid volume regulation mechanisms with dual stimuli. One of these is of 
volume stimulus and the other is an osmotic stimulus, primarily due to sodium concentration.

The HR group responded preferentially to the osmotic stimulus, becoming oligouric. Precedence was placed on sodium plasma concentration. The response to volume expansion was antidiuresis. The increase in urine sodium concentration in the HR treatment group is attributable to the plasma $\mathrm{NaCl}$ load this group experienced. Due to the indiscriminate nature of glomerular filtration, it is presumed that the tubular load of sodium was greater in the HR treatment group. Tubule sodium concentration and filtrate flow rates have a direct effect on the amount of sodium reabsorbed in mammals (Guyton 1991). According to Guyton, sodium is transported in mammalian proximal tubule cells via a gradient-time transport mechanism. The transport depends on the lumentubule cell sodium concentration gradient as well as the amount of time the filtrate is in the lumen (luminal flow rate). Distally, sodium transport is of the more conventional type, i.e. tubular maximum transport rates are based on the number of sodium pumps present. This may be the case for amphibian transport processes as well.

At high flow rates, tubular uptake mechanisms may be unable to remove the sodium present in the filtrate due to the high rate of filtrate flow even though concentration is not sufficient for saturating transport processes. Multiple regression for the hypoosmotic data supports this (Table V). When UFR was elevated (30 minutes post infusion), urine sodium concentration was also high (Figures 4 and 7). The occurrence of high UFRs with high urine sodium concentrations (Figure 10) suggests that the flow rate in the nephron may have overwhelmed the ability of the 
luminal cell transport mechanisms to remove much sodium. At low UFRs, as in the HR group (Figure 7), urine sodium was also high (Figure 4). This suggests tubular sodium transport mechanisms were inhibited or saturated, leaving more sodium in the urine. However, urine sodium levels may also be due to increased flow rate. An apparent saturation kinetic response with the accompanying high urine sodium concentration was observed by Hillman and Schimpf (1994). Implications of this effect on organismal sodium balance are discouraged as anurans may reclaim water and ions from the bladder (Bentley 1966) as physiological needs dictate. This apparent organismic "loss" of sodium is negated. This differs from mammalian systems where bladder contents are not available for reabsorption.

Natriuresis is the product of urine sodium concentration and urine flow rate. For both treatments, these two variables were significant contributors to natriuresis (Table IX). Results of multiple regression showed a reversal in the dominance of UFR and urine sodium concentration in determining natriuresis (Table IX) for the treatments. The natriuresis of the HO group was determined mostly by the sodium concentration of the urine, while depressed UFR was more instrumental in determination of natriuresis for the HR group. The HR group had low UFRs, so the sodium uptake mechanisms were likely saturated for the urine to contain such large quantities of sodium (Figure 4). Natural expansions of blood volume for $B$. marinus are hypoosmotic (i.e., cutaneous or bladder influx of water), which would increase plasma volume and decrease plasma osmotic pressure. The situation of saline loading is not a natural one for these animals, but it allows for consideration of effects of volume expansion with the presence of 
an osmotic stimulus. Hillman and Schimpf (1994) expanded the blood volume of $B$. marinus isosmotically and observed an intermediate response of UFR and natriuresis, relative to hypo- and hyperosmotic expansions.

The HO treatment yielded relatively high sodium concentrations in the urine at 30 minutes post infusion, which was when UFR peaked for this group. With high UFRs, filtrate flow rates may be sufficient to overcome transport and end up in the urine. In blood volume expanded dogs, an increase in natriuresis has been observed (Bahlmann et al. 1967; Rector et al. 1964) and determined to be a result of diminished tubular reabsorption (Rector et al. 1964), confirming either transport saturation or increased filtrate flow allowing sodium to bypass transport processes.

For the HR group, potassium concentrations in the urine were significantly higher than the values observed for the HO treatment. An effect that may be partially responsible is the action of $\mathrm{Na} / \mathrm{K}$ exchange transporters. These transport proteins are located in the basolateral membranes of luminal cells. Since the basolateral pumps would have increased activity due to the high sodium filtrate concentration, more potassium would be present in the intracellular space. With a high intracellular potassium concentration, more potassium is present to diffuse down concentration gradients, namely into the luminal space. This increased concentration of potassium may facilitate the lumenward diffusion necessary to achieve the observed high potassium urine concentrations.

In the HO group, it is interesting that high UFRs coincided with an increased urine potassium concentration (Figure 11). This is similar to the 
condition of urine sodium concentration. This suggests that the toads may be unable to conserve ions renally at high urine flow rates.

As kaliuresis is the product of UFR and urine potassium concentration, it is little surprise that the $\mathrm{HO}$ group showed such a great increase in kaliuresis at 30 min post infusion, when UFR was maximal. Multiple regression showed that urine flow rate was the most heavily weighted independent variable in determination of kaliuresis, with urine potassium second (Table XI). Except at $30 \mathrm{~min}$, both groups decreased kaliuresis during the experiment, an overall conservation of this important ion. 
SUMMARY

The most surprising result was the apparent lack of effect of rate of infusion on UFR, GFR, and ion excretion rates both in short term (during infusion) and long term (90 min) situations. It seemed rate of volume expansion was not crucial in the determination of observed responses.

UFR and GFR were highly correlated with each other for both treatments. At high GFRs, there is a divergence of data for UFR, the difference between treatments is apparent. Indications are that at high GFRs, the difference between UFR response is due to tubular processes.

The urine volume produced by the HR group was less than half that produced by the HO group. Tubular uptake mechanisms must account for the difference in UFR response, since GFR response was fundamentally the same with respect to an initial increase to similar values (Figure 8). The difference was that the HR group displayed a faster decline following the initial rise. As GFR for the HR group rose initially, the volume stimulus initially overrode the osmotic stimulus in determining GFR. Decreased urine volume in HR group, coupled with the high sodium load, worked synergistically to give the observed high urine sodium concentration. The HR group responded to the osmotic and volume stress by excreting significantly higher sodium concentrations in urine while becoming increasingly anuric.

In the HO group, GFR and UFR increased. An increase in water concentration for this group may be the reason for this classic diuretic response to decreased plasma solute loads. In response to volume expansion and a reduced plasma sodium concentration, the homeostatic 
priority was to return the plasma volume to a lower level, disregarding the accompanying sodium loss. The volume stimulus resulted in an override of sodium conservation mechanisms (Figure 10).

As volume expansions likely stimulate the release of ANF (DeBold 1985), it must be considered to play a role in effecting the natriuresis at least for the HO expansion. Assays for circulating ANF levels in both $\mathrm{HO}$ and HR expansion would be of interest. ANF may be responsible for some of the natriuresis in the hypoosmotic group, if so, however, it's "control" is overridden in the HR group, as the natriuresis was not nearly so pronounced (Figure 12).

From an organismal perspective, terrestrial amphibians experience hypoosmotic blood volume expansion as a result of transcutaneous and bladder water uptake. Renal responses to this expansion have been delineated in this paper. However, the overall organismal effect of renal responses are not obvious. The ability to reasbsorb water and solutes from the bladder could modify the urine solute and water concentration, therefore, net solute and water excretion are not directly measured by renal responses. 
REFERENCES CITED

ADOLPH, E. F., 1927. The excretion of water by the kidneys of frogs. Am. J. Physiol. 81:315-324.

BAhlmanN, J., S. J. MC Donald, M. G. Venton, and H. E. De WARDENER, 1967. The effect of urinary sodium excretion of blood volume expansion without changing composition of blood in the dog. Clin. Sci. 32: 403-413.

BENTLEY, P. J., 1966. The physiology of the urinary bladder of Amphibia. Biol. Rev. 41:275-316.

BENTLEY, P. J., 1969. Neurohypophysial function in amphibia: Hormone activity in the plasma. J. Endocrinol. 43:359-369.

BENTLEY, P. J., 1973. Osmoregulation in the aquatic urodeles Amphiuma means (the Congo eel) and Siren lacertina (the mud eel). Effects of vasotocin. Gen. Comp. Endocrin. 20:386-391.

BenTLEY, P. J., 1976. Hormones and Osmoregulation in Comparative Vertebrate Endocrinology. Pages 275-308. Cambridge University Press. Cambridge, London, New York, Melbourne.

BOULPAEP, E. L., 1971. Electrophysiologic properties of the proximal tubule: importance of intercellular transport and extracellular pathways. Pages 91-118. in G. GIEBISCH, ed. Electrophysiology of Epithelial Cells. Symp. Med. Hoechst. Stuttgart-Schattauer.

DE BOLD, A. J., 1985. Atrial natriuretic factor: a hormone produced by the heart. Science 230:767-770.

DIETZ, J. R., 1984. Release of natriuretic factor from rat heart-lung preparation by atrial distension. Am. J. Physiol. 247 (Regulatory Integrative Comp. Physiol. 16): R1093-1096. 
ELIASSEN E., and C. B. JøRGENSEN C.B. ,1951. The effect of increase in osmotic pressure of the body fluid on the water balance of anurans. Acta. Physiol. Scand. 23:143-151.

FORSTER, R. P., 1938. Use of inulin and creatinine as glomerular filtrate measuring substances in the frog. J. Cell. Comp. Physiol. 12(2):213222.

FORSTER, R. P., 1942. The nature of the glucose reabsorptive process in the frog renal tubule: Evidence for intermittency of glomerular function in the intact animal. J. Cell. Comp. Physiol. 20:55-69 (5).

GRANDChAMP, A., and E. L. BOULPAEP, 1974. Pressure control of sodium reabsorption and intercellular backflux across the proximal kidney tubule. J. Clin. Invest. 54:69-82.

GUYTON, A. C., 1991. Textbook of Medical Physiology, eighth edition. W. B. Saunders Company. Philadelphia.

HENDRIX, J. P., B. B. WESTFALL, and A. N. RICHARDS, 1937. Quantitative studies of the composition of glomerular urine. XIV. The glomerular excretion of inulin in frogs and Necturi. J. Biol. Chem. 116:735.

HILlmaN, S. S., 1978a. Some effects of dehydration on internal distributions of water and solutes in Xenopus laevis. Comp. Biochem. Physiol. 61A: 303-307.

HILLMAN, S. S., 1978b. The roles of oxygen delivery and electrolyte levels in the dehydrational death of Xenopus laevis. J. Comp. Physiol. 128:169175.

HILlmaN, S. S., 1980. Physiological correlates of differential dehydration tolerance in anuran amphibians. Copeia. 1:125-129. 
HILlmaN, S. S., and P. C. WITHERS, 1988. The hemodynamic consequences of hemorrhage and hypernatremia in two amphibians. J. Comp. Physiol. 157B:807-812.

HILLMAN, S. S., and B. SCHIMPF, 1994. Renal responses to blood volume expansion of varying osmotic concentrations and atriopeptin infusion in two species of amphibian, Bufo marinus and Rana catesbeiana. Physiol. Zool. 67(4):995-1005.

HillmaN, S. S.,'P. C. WITHERS, M. S. HedRICK, and P. B. KIMMEL, 1985. The effects of erythrocemia on blood viscosity, maximal systemic oxygen transport capacity and maximal rates of oxygen consumption in an amphibian. J. Comp. Physiol. 155:577-581.

ISHII, K., and K. ISHII, 1978. A reflexogenic area for controlling the blood pressure in toad (Bufo vulgaris formosa). Jap. J. Physiol. 28:423-431.

LANG, R. E., H. RuskoAho, M. TOTh, D. GANTEN, T. UNGER, and R. DiETZ, 1987. Mechanisms Controlling Release of Atrial Natriuretic Peptide. in P. J. MULROW and R. SCHRIER, eds. Atrial Hormones and Other Natriuretic Factors. Waverly Press Inc., Baltimore.

LEVINSKY N.G., and W. H. SAWYER, 1953. Significance of the neurohypophysis in regulation of fluid balance in the frog. Proc. Soc. Exp. Biol. Med. 82:272-274.

MAUDE, D. L., I. SHEHADEH, and A. K. SOLOMON, 1966. Sodium and water in single perfused distal tubules of Necturus kidney. Am. J. Physiol. 221:1043-1049.

MIDDLER, S. A., C. R.. KLEEMAN, and E. EDWARDS, 1968. The role of the urinary bladder in salt and water metabolism of the toad Bufo marinus. Comp. Biochem. Physiol. 26:57-68. 
MidDLER, S. A., and C. R. KLEEMAN, 1973. Method of ureteral catheterizaton and hypophysectomy of the toad. Pages 27-39 in J. F. GROSS, and E. WETTERER eds. Modern Techniques in Physiological Sciences. Academic Press, London, New York, 1973.

MORRIS, J. L., and I. L. GIBBINS, 1983. Innervation of the renal vasculature of the toad (Bufo marinus). Cell Tiss. Res. 231:357-376.

NAVAR, L. G., and A. C. GUYTON, 1975. Intrarenal mechanisms for regulating blood fluid volume. in A. C. GUYTON, A. E. TAYLOR, and H. J. GRANGER, eds. Circulatory Physiology II: Dynamics and control of the body fluids. W. B. Saunders Company, Philadelphia.

PANG, P. K. T., S. M., Galli-Gallardo, N. Collie, and W. H. SAWYER, 1980. Renal and peripheral vascular responsiveness to arginine vasotocin in the bullfrog Rana catesbeiana. Am. J. Physiol. 239:R156 $-\mathrm{R} 160$.

PERSSON, B. E., and D. J. MARSH, 1987. GFR regulation and flow-dependent electrophysiology of early distal tubule of Amphiuma. Am. J. Physiology. 253:F263-F268.

Persson, B. E., and A. E. G. PERSSON, 1981. The existence of a tubuloglomerular feedback mechanism in the Amphiuma nephron. Pflug. Archiv. 392(5):129-134.

RECTOR, F. C., JR., G. VAN GIESEN, F. KIIL, and D. W. Seldin, 1964. Influence of expansion of extracellular volume on tubular reabsorption of sodium independent of changes in glomerular filtration rate and aldosterone activity. J. Clin. Invest. 43(3):341-356. 
RICHARDS, A. N., and C. F. SCHMIDT, 1924. A description of the glomerular circulation in the frog's kidney and observations concerning the action of adrenalin and various other substances upon it. Am. J. Physiol. 71:178-208.

RUIBAL, R., 1962. The adaptive value of bladder water in the toad Bufo cognatus. Physiol. Zool. 35:218-223.

SAWYER, W. H., 1951. Effect of posterior pituitary extracts on urine formation and glomerular circulation in the frog. Am. J. Physiol. 164:457-466.

SAWYER, W. H., 1957. Increased renal reabsorption of osmotically free water by the toad Bufo marinus in response to neurohypophyseal hormones. Am. J. Physiol. 189(3):564-568.

SCHMIDT-NIELSEN, B., and R. P. FORSTER, 1954. The effect of dehydration and low temperature on renal function in the bullfrog. J. Cell. Comp. Phys. 44:233-246.

SPOTILA, J. R., and E. N. BERMAN, 1976. Determination of skin resistance and the role of the skin in controlling water loss in amphibians and reptiles. Comp. Biochem. Physiol. 55:A407-411 .

STIFFLER, D. F., B. J. ATKINS, L. D. BURT, and S. C. ROACH, 1982. Control of renal function in larval Ambystoma tigrinum. J. Comp. Physiol. 149:91-97.

SULLIVAN, J., 1968. Electrical potential differences across distal renal tubules of Amphiuma. Am. J. Physiol. 214:1096-1103.

TUFTS, B. L ., and D. P. TOEWS, 1986. Renal function and acid base balance in the toad Bufo marinus during short term dehydration. Can. J. Zool. 64:1054-1067. 
URANGA, J., 1963. The influence of changes in plasma volume on GFR and ureteral pressure in the toad. Acta physiol. lat. amer. 13:177-183.

URANGA, J., 1965. Relationship between plasma volume and plasma flow in the toad. Acta physiol. lat. amer. 15:215-217.

VAN VLIET, B. N., and N. H. WEST, 1986a. Response characteristics of pulmocutaneous arterial baroreceptors in the toad, Bufo marinus. J. Physiol. 388:55-70.

VAN VLIET, B. N., and N. H. WEST, 1986b. Cardiovascular responses to electrical stimulation of the recurrent laryngeal nerve in conscious toads (Bufo marinus ). J. Comp. Physiol. 156:363-375.

WILBRANDT, W., 1938. Electrical potential differences across the wall of the kidney tubules of Necturus. J. Cell. Comp. Physiol. 11:425-431.

YATZIDIS, H. 1976. Simplified determination of plasma inulin in testing kidney function. Clin. Chem. 22:1239. 